Blanca Fernandez Milan, David Kapfer, Felix Creutzig

\title{
A systematic framework of location value taxes reveals dismal policy design in most European countries
}

\section{Article, Postprint}

This version is available at http://dx.doi.org/10.14279/depositonce-5769.

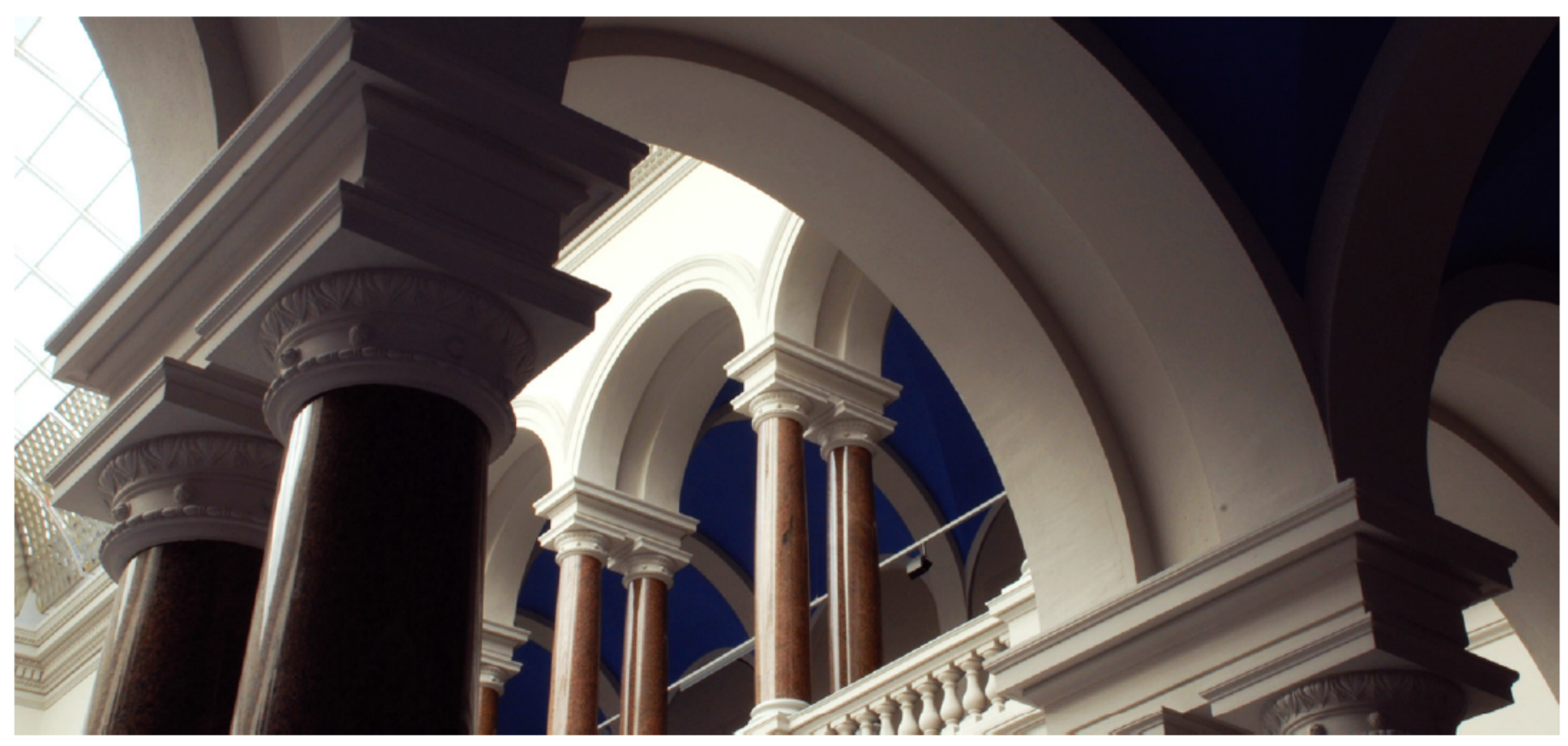

\section{Suggested Citation}

Fernandez Milan, Blanca; Kapfer, David; Creutzig, Felix: A systematic framework of location value taxes reveals dismal policy design in most European countries. - In: Land Use Policy. - ISSN: 0264-8377

(online). 51 (2016). - pp. 335-349. - DOI: 10.1016/j.landusepol.2015.11.022. (Postprint version is cited, page numbers differ.) 


\title{
A systematic framework of location value taxes reveals dismal policy design in most European countries
}

\author{
Blanca Fernandez ${ }^{1,2,}$, David Kapfer ${ }^{1,2}$, Felix Creutzig ${ }^{1,2}$
}

\begin{abstract}
Location values have long been recognized as an attractive instrument to raise municipal revenues. First, they increase fiscal efficiency and equability compared to traditional property taxes. Second, they can be used to enhance sustainable urban planning. The question of how to design a location value tax has long been discussed in various strands of literature, but there are few efforts to create multidisciplinary approaches. This lack of reconciliation hampers the discussion on optimal designs that includes all economic, social and environmental considerations. Here we combine literature on public finances, urban economics and value capture with that of sustainable urban planning to narrow this gap. We develop a framework to assess the design characteristics of location value taxes from a sustainability perspective, and apply this framework to assess current practices in Europe. The analysis reveals severe shortcoming in policy design in most European countries, although Denmark provides a more promising example. Nonetheless location value taxes have a high potential for improving sustainable urban planning.
\end{abstract}

Keywords: location value tax; urban sustainability; European property taxation.

\footnotetext{
${ }^{1}$ *(Corresponding author) Mercator Research Institute on Global Commons and Climate Change Berlin

${ }^{2}$ Technical University Berlin, Department of Economics of Climate Change
} 


\section{The rationale of a location value tax for urban sustainability}

Cities constitute both sources and solutions to climate change and other sustainability challenges. While diverse disciplines address some aspects of urbanization, there is a need to integrate this knowledge in order to find optimal - or at least appropriate - pathways that could minimize the negative impacts as well as maximize the positive outcomes of the urbanization process (Rosenzweig et al. 2011; Seto et al. 2014). Solutions are strongly related to policy instruments that enhance synergies among multiple objectives, and well-designed urban plans exhibit great potential (Seto et al. 2014; Zanon and Verones 2013). On the one hand, they efficiently limit urban externalities (R. Arnott 2011; Brueckner and Kim 2003; Kaza and Knaap 2011). On the other hand, they may alleviate municipal budget constraints (especially in Europe) for low carbon urban infrastructure investment (Dexia and CEMR 2012; Mathur and Smith 2013; Rybeck 2004).

Location Value Tax (LVT), a tax that recovers the value of properties that has not been created by landowners, could explicitly support sustainable urban planning objectives (Batt 2011a; Brandt 2014; Panella, Zatti, and Carraro 2011; UNHABITAT 1976; UN-HABITAT 2011b) (we argue in favour of using the concept LVT instead of the common term Land Value Tax based on a proposal to homogenise nomenclature; see Figure 1 in Section 3.1 for clarification). First, it increases fiscal efficiency. As the provision of land remains cost-free, taxing away urban location values (LV) does neither harm the economy nor does it distort markets (George 1879; Kunce and Shogren 2008; Mattauch et al. 2013). Revenues have been used to finance sustainable urban infrastructure in different contexts ${ }^{3}$ (Ingram and Hong 2012b; Kitchen 2013; Medda 2012; UN-HABITAT 2011b; Zhao et al. 2012). Second, it is legitimate to tax away LV. The share of property's worth which is not produced by landowner's labour, but from public intervention, community actions and environmental quality, is an unfair burden on those whose activities had given it value (Albouy 2012; Albouy 2009; R. J. Arnott and Stiglitz 1979; Brandt 2014; Brueckner 2000; Fainstein 2012; Mattauch et al. 2013; UNHABITAT 1976). These capitalization dynamics, exacerbated in the last decade, have provoked a strong call for reconsidering the property tax (PT) base and shift it from real estate towards LV for wealth distributional objectives (Seely 2013b; H. J. Brown and Smolka 1997; Terry Dwyer 2003; European Environment Agency 2010; F. E. Foldvary 2006; Gaffney 2009; Institute for Fiscal Studies and Mirrlees 2011; D. E. Mills 2001; Oates and Schwab 2009a; Raslanas 2013; UN-HABITAT 2011a). Third, a tax on LV fosters sustainable urban development in the following ways: (a) it reduces urban land conversion trends (Altes 2009; Banzhaf and Lavery 2010; Brueckner 2000), (b) it fosters mixed land use development and by this supports low-carbon transport modes (Altes 2009; Nuissl and Schroeter-Schlaack 2009), and

\footnotetext{
${ }^{3}$ (Cord 1985) found that an annual land rent tax would yield nearly two-thirds of all taxes in place for the U.S.
} 
(c) it internalizes externalities, especially those related to environmental degradation (Brandt 2014; European Environment Agency 2010). The fact that more than 30 states use some form of LVT demonstrates that it is far from being a utopian concept (J. E. Anderson 2009; Richard M. Bird and Slack 2003; Bourassa 2009; Johannesson Lindén and Gayer 2012; McCluskey and Franzsen 2005).

While there seems to be a common consensus of the benefits from LVT, literature lacks in conclusive outcomes with regards to optimal designs, particularly for fairness and land consumption concerns (Brueckner and Kim 2003; Cho et al. 2008; Dye and England 2009b; Ingram 2008; Lim 1992; Luca 2011; Maxwell and Vigor 2005; Oates and Schwab 1997; Skaburskis 1995; Song and Zenou 2006; UNHABITAT 2011a). Three important shortcomings appear in the literature. First, diverse disciplines investigate different aspects of LVTs, but vague terminology and inconsistencies disable useful comparisons between outcomes (Richard M. Bird and Slack 2003; Doerner and Thlanfeldt 2011; Dye and England 2009b; England 2003; F. E. Foldvary 2006; Institute for Fiscal Studies and Mirrlees 2011; Lutz, Molloy, and Shan 2011; Raslanas 2013). Second, evaluation lacks a systemic holistic perspective that covers all potential benefits at the same time (Alterman 2011; Cocconcelli and Medda 2013; Riël C.D. Franzsen and William 2008; Luca 2011; Maxwell and Vigor 2005; McCluskey and Franzsen 2005; UN-HABITAT 2011a; UN-HABITAT 2011b). Finally, empirical studies deal with very specific set-ups where evidence comes only from observing the effect of changes in tax regimes, and remains incoherent as evaluation depends also on baseline conditions (initial tax regime), and institutional and macroeconomic contexts (J. E. Anderson 2009; Riel C. D. Franzsen 2009).

We seek to alleviate these shortcomings by critically reviewing and comparing current theoretical and practical approaches to LVT in cities under a sustainable perspective. Sustainability here indicates the set of effects in urban land (developed or developable) induced by shifting PT towards LVT on economic, social and environmental systems, by assembling those independently identified in the literature. On this basis, we answer the following research questions:

a. Which design characteristics of LVT are enhancers of urban sustainability?

b. Are current European practices of LVT properly designed according to what literature says?

Section 2 describes a framework to assess outcomes from different LVT design characteristics. We use this framework for the evaluation of current European practices in Section 4. Finally in Section 5 conclusions are drawn as to whether LVT may be a useful instrument to complement other planning measures. Our research indicates that LVT is a valid option for future fiscal reforms from an urban sustainability perspective, but outcomes strongly depend on the instrument design characteristics as well as on the urban context. 


\section{Design elements of LVT: A framework}

This section reviews and synthetize the literature dealing with LVT to address the first question, combining findings from the fields from urban economics, public finances and property taxation, urban sustainability planning and value capture. We develop a framework that assists in the evaluation of a shift towards LVT from a holistic perspective, considering the potential effects different tax designs may have on different aspects of urban sustainability, understood as a term that embraces not only pure economic efficiency improvements in the fiscal system and revenue potential (Clark and Jamelske 2005; Cord 1985; England 2007; England 2003; Nechyba 1998), but also social and environmental ones. Social sustainability entails on the one hand the progressivity of the LVT (based on public economic literature) (George 1879; Musgrave 1974; Youngman 2002), and the equitable access to public intervention on the other (taken from sustainability and development literature) $(\mathrm{N}$. Dempsey, Brown, and Bramley 2012; Nicola Dempsey et al. 2011; Fernandez Milan 2015). Environmental sustainability in cities may include multiple aspects. We focus on excessive urban land consumption (also known as urban sprawl) (see e.g. (Cho et al. 2008; England and Ravichandran 2010; Lim 1992), and environmental pollution to a lesser extent (often refer to as environmental externalities) (Alterman 2011; Batt 2011b). Our evaluation toolkit structures typically discussed issues on which policy-makers take decisions when developing and implementing a LVT into ten main design characteristics (Alterman 2011; Dye and England 2009a) (see Table 1 below).

Table 1. Design characteristics of LVT influencing sustainability effects. $\mathrm{X}$ indicates the most suggested option literature refers to when looking at the sustainability effects. Abbreviation characters explained in Table 2.

\begin{tabular}{lll}
\hline 1. Tax base & Criterion & Sub-criterion \\
& Natural resources (N) \\
& Private improvements: investment nearby (T) \\
& Environmental Externalities (Q) \\
& I Public/ Community intervention (C) \\
& I Public intervention: Urban infrastructure (E) \\
& II Public intervention: Land-use regulations (O) \\
& Private improvements-owner: non-structural (M) \\
& Private improvements-owner: structural (G) \\
& Site Value (S) (T+Q+C+E+O1+M) \\
& Location Value (LV) (T+Q+C+E+O) \\
& Land Value (H) (T+Q+C+E+O+M+N) \\
& All urban owners (AUO) \\
& Private ownership (PO): Private owner-occupied (POo) and \\
& Private owner non-occupied (POn) \\
2. Tax subject - & Legal Entities (LE): Legal Enterprise (LEn), Public (P) and \\
Ownership & Institutional (I) \\
\hline Tenants/ Users (U) \\
\hline
\end{tabular}


Table 1 cont (1).

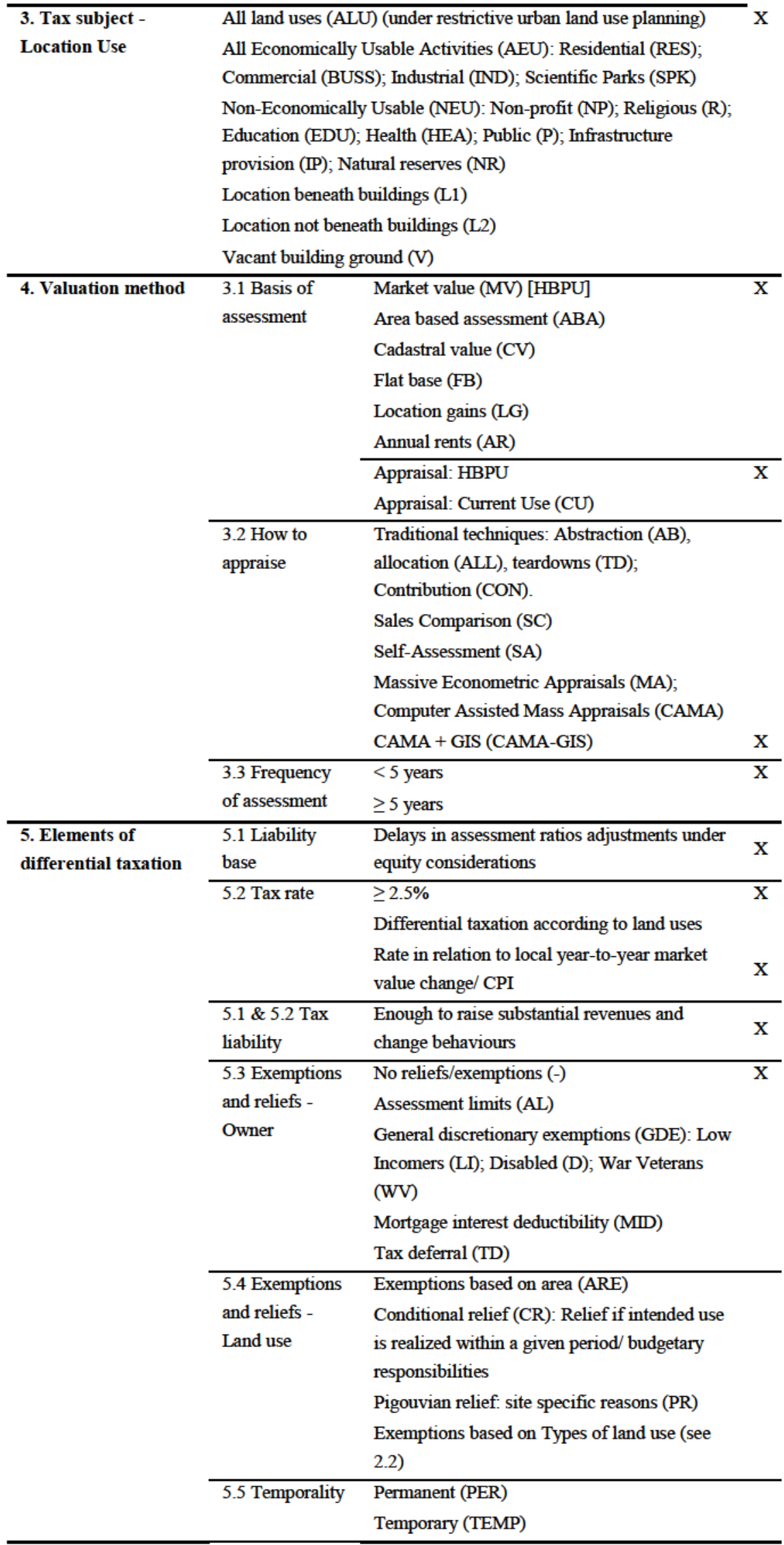


Table 1 cont (2).

\begin{tabular}{|c|c|c|c|}
\hline \multirow[t]{4}{*}{ 6. Revenue raising } & $\begin{array}{l}6.1 \text { Tax } \\
\text { liability }\end{array}$ & $\begin{array}{l}\text { Minimum criteria: payment obligations cover } \\
\text { administrative costs }\end{array}$ & $\mathrm{X}$ \\
\hline & 6.2 & $R_{r} \geq$ predefined value & $\mathrm{x}$ \\
\hline & Collection & $R_{i} \geq$ predefined value & $\mathrm{x}$ \\
\hline & [Normative] & $R_{r}(t)$ constant & $\mathrm{X}$ \\
\hline 7. Revenue recycling & \multicolumn{3}{|c|}{$\begin{array}{l}\text { [Normative] Locally - Benefit view (BV), Redistribution - New } \\
\text { view (NV) }\end{array}$} \\
\hline \multirow[t]{5}{*}{ 8. Governance } & 8.1 Tax & Local Government (L) & $\bar{X}$ \\
\hline & Base; 8.2 & Regional or State (C) & \\
\hline & Tax Rate; 8.3 & State and Local (C/L) & \\
\hline & Reliefs; 8.4 & Local within state set range $(C(L))$ & \\
\hline & $\begin{array}{l}\text { Collection; } \\
8.5 \text { Revenues }\end{array}$ & Local within LUZ set range (LUZ(L)) & $\mathrm{x}$ \\
\hline \multirow[t]{2}{*}{ 9. Fiscal Environment } & \multicolumn{2}{|c|}{ No taxes related to property (No) } & $\bar{X}$ \\
\hline & \multicolumn{2}{|c|}{ Additional taxes related to property (Yes) } & \\
\hline \multirow[t]{6}{*}{ 10. Implementation } & \multicolumn{2}{|c|}{ 10.1 Legal separation } & $\mathrm{X}$ \\
\hline & \multicolumn{2}{|c|}{ 10.2 Taxpayer's right to require a revision of the valuation } & $\mathrm{x}$ \\
\hline & \multicolumn{2}{|c|}{ 10.3 Explicit tax bills and revenue recycling } & $\mathrm{x}$ \\
\hline & \multicolumn{2}{|c|}{ 10.4 Strong land use planning } & $\mathrm{X}$ \\
\hline & \multicolumn{2}{|c|}{ 10.5 Coordination among tax offices } & $\mathrm{x}$ \\
\hline & \multicolumn{2}{|c|}{ 10.6 Gradual introduction } & $\mathrm{X}$ \\
\hline
\end{tabular}

\subsection{Tax base}

\subsubsection{What can be taxed?}

Terms like "site value"; "location value", and "value capture" are used interchangeably in the literatures creating inconsistencies (Franzsen and William 2008; Hubacek and van den Bergh 2006; Özdilek 2011; Park 2014). An established nomenclature would facilitate the discussion (Özdilek 2011; Hubacek and van den Bergh 2006; Park 2014). Two issues are crucial for this exercise: a) where does the value come from, and b) who creates the value (Huxley 2009; Rybeck 2004; Ingram and Hong 2012b; Zhao et al. 2012; Rao 2008; Grosskopf 1981; Brueckner 1986; Riël C.D. Franzsen and William 2008; Alterman 2011); both necessary for the applicability of political rationales. Few attempts on classifications and methodological guidelines exist (Alterman 2011; Ingram and Hong 2012a; Medda 2012), but none is exhaustive enough to cover all three sustainability criteria we here deal with.

In our attempt to bridge the gap between literatures, we identify the value elements that comprise property values and their value sources. Literatures also use terms that aggregate a number of value elements, but these are never appropriately clarified. We disentangle them and delineate them with their "element mix", to define them in a systematic way. Fig. 1 and Table 2 below show the different elements and aggregated value terms coming out of this exercise. 


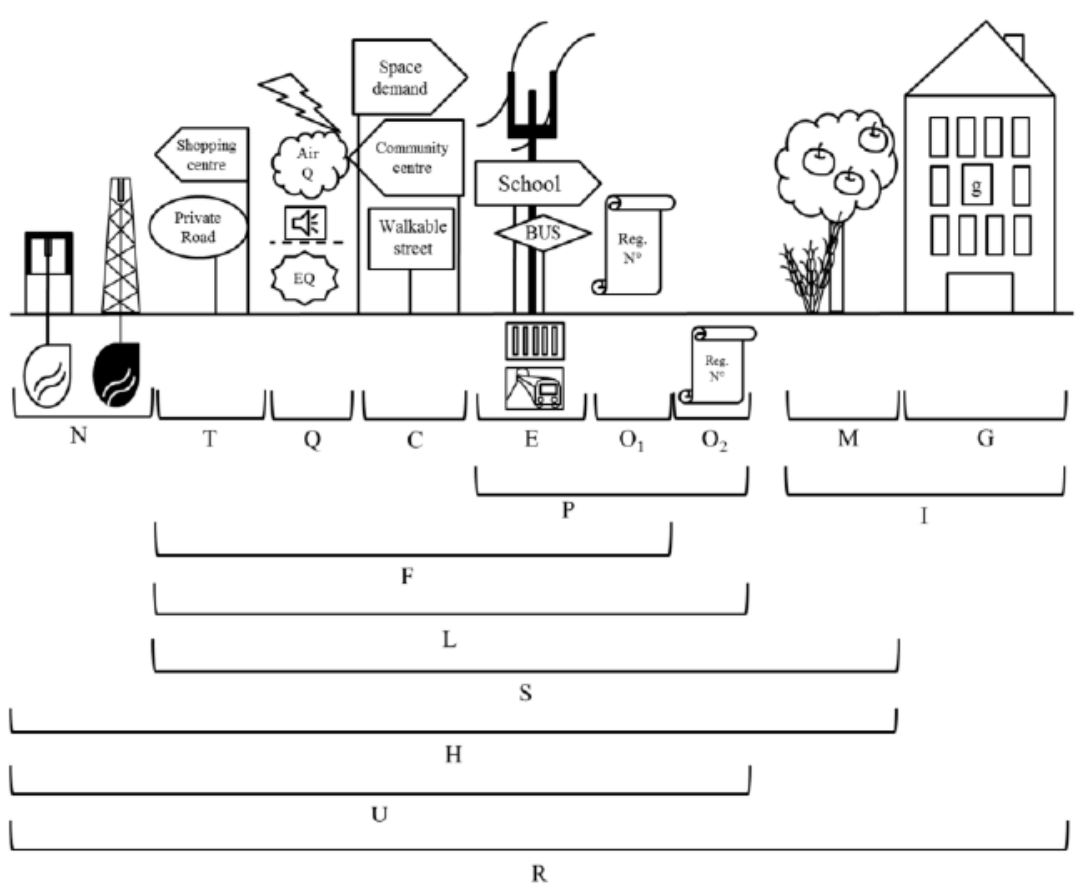

Figure 1 Nomenclature: Conceptual Diagram

Table 2 Nomenclature: Definitions

\begin{tabular}{|c|c|c|}
\hline Sign & Nomenclature & Example/ Definition \\
\hline \multicolumn{3}{|c|}{ Element } \\
\hline $\mathrm{N}$ & Natural resources (including land productivity) & Minerals, oil, water bodies, soil \\
\hline $\mathrm{T}$ & Private improvements: investment nearby & Shopping centre, private road \\
\hline Q & Environmental externalities & Air Q., noise, radiation. \\
\hline $\mathrm{C}$ & I Public/ Community intervention & $\begin{array}{l}\text { Space demand }{ }^{4} \text {, community } \\
\text { attractiveness. }\end{array}$ \\
\hline $\mathrm{E}$ & II Public intervention: Urban infrastructure & Transport, sewage, electricity \\
\hline $\mathrm{O}$ & III Public intervention: Land-use regulations & $\mathrm{O} 1$ : Zoning; $\mathrm{O} 2$ : use rights \\
\hline M & Private improvements-owner: non-structural & Garden, irrigation system \\
\hline G & Private improvements-owner: structural & House, dwellings \\
\hline $\mathrm{g}$ & Private improvements-owner: structural & Apartment or part of building \\
\hline \multicolumn{3}{|c|}{ Aggregated Value } \\
\hline $\mathrm{P}$ & Value from public intervention & $\mathrm{E}+\mathrm{O}$ \\
\hline I & Value from private improvements-owner & $\mathrm{M}+\mathrm{G}$ \\
\hline $\mathrm{F}$ & Location surface value & $\mathrm{T}+\mathrm{Q}+\mathrm{C}+\mathrm{E}+\mathrm{O} 1$ \\
\hline L & Location value & $\mathrm{T}+\mathrm{Q}+\mathrm{C}+\mathrm{E}+\mathrm{O}$ \\
\hline S & Site value & $\mathrm{T}+\mathrm{Q}+\mathrm{C}+\mathrm{E}+\mathrm{O}+\mathrm{M}$ \\
\hline $\mathrm{H}$ & Land values & $\mathrm{T}+\mathrm{Q}+\mathrm{C}+\mathrm{E}+\mathrm{O}+\mathrm{M}+\mathrm{N}$ \\
\hline $\mathrm{U}$ & Unearned value & $\mathrm{C}+\mathrm{E}+\mathrm{O}+\mathrm{Q}+\mathrm{T}+\mathrm{N}$ \\
\hline $\mathrm{R}$ & Real estate/ Property value & $\mathrm{U}+\mathrm{I}$ \\
\hline $\mathrm{W}$ & Immobile wealth & Depends on definition of wealth \\
\hline
\end{tabular}

${ }^{4}$ Space demand is what often is referring to as urban development macro-effects: population increase, economic development (income) Security, income, and agglomeration effects among others. 


\subsubsection{What should be taxed?}

Defining which value should remain in which hands is a normative issue with philosophical implications. Some authors claim that land productivity should be added to that of private land improvements and remain in private hands because it is already paid for by the owner at the time of acquisition (Ingram and Hong 2012a). Others use the case of larger natural resources to make the case for taxing them (Alterman 2011) $)^{5}$. Significant differences between natural resources and the rest of value elements on how the value is created, capitalized and assessed, leads to different outcomes depending on whether they are included or not in the tax base. Taxing natural resources encourages over-exploitation, whereas a tax on extraction outputs -e.g. through a sufficiently high environmental consumption taxdiscourages it and leaves the resources underground for future generations. Hence, natural resources should be addressed with an independent instrument which taxes the extraction rent, not the value element (Gaffney 2009).

A wide agreement exists on capturing value from infrastructure improvements and public services (UN-HABITAT 1976; L. W. Walters 2012). Although it raises political opposition (Dillman and Fisher 2009), the same occurs with the value from changes in land use regulations. Land use regulations create artificial land scarcity, and building regulation constraints supply through height and density constraints, both inflating location prices ${ }^{6}$ (The Economist 2015; UN-HABITAT 1976; L. W. Walters 2012). Community-related value, forgotten in the value capture literature, it is included in the tax base under wealth redistribution arguments (UN-HABITAT 1976; L. W. Walters 2012). Finally, the value from environmental externalities, only mentioned in new development, should also be part of the LVT for environmental concerns (Pigouvian taxation) (Batt 2011a; European Environment Agency 2010; Kunce and Shogren 2008; Panella, Zatti, and Carraro 2011). This said, LV is the least economically distortive aggregated value (Recktenwald and Smith 1999; Mill 1985; George 1879; F. E. Foldvary 2006; F. E. Foldvary 2008; F. Foldvary 2010); one of the fairest tax base (Harrison 2014; F. E. Foldvary 2008; Gaffney 2009), and discourages extensive, space-consuming urbanization by fostering intensive use of urban land (F. E. Foldvary 2008). Weaknesses only appear when it comes to implementation (Ingram and Hong 2012a).

\subsection{Ownership}

Two types of individual entities constitute private property ownership: residential owners - owner that is registered at the location -, and non-residential owners - not registered at the location -. Tenants, users or renters also hold specific rights and duties. An increase in LV affects only tenants because they suffer a proportional

${ }^{5}$ An oil discovery near Gatwick (London, UK) has brought this issue to the front of the discussion (Barrett 2015).

${ }^{6}$ In West End London (UK) land-use regulations inflate LV by about 800 percent; in Milan and Paris by 300 percent approx. (The Economist 2015). The absolute liberalization of the real estate market in the US would yield about $\$ 1.5$ trillion, rising GDP by between 6 and 13 percent (The Economist 2015). 
increase in their rents, sometimes high enough to cause displacements. Nonresidential owners see their revenues climbing with zero additional investment costs. Residential owners can either sell their property and capitalize the added value, or stay and pay unchanged mortgages. Hence, added values are captured by ownership, and it is thus acceptable to tax only owners, disabling them to pass the charge to renters (Dye and England 2009b; F. E. Foldvary 2008; Ingram and Hong 2012b; Mattauch et al. 2013; Mill 1985; UN-HABITAT 2011b). Next, three types of legal entities exist: Legal Enterprise, Public bodies, and Institutions. An optimal LVT should apply to all urban ownerships to avoid underuse and suboptimal allocation of untaxed land (Alterman 2011), especially in countries with a large share of public land (Waicho Tsui 2008).

\subsection{Land-uses}

The chargeable subject mostly varies depending on the type of human activity allowed. First, a LVT can be applied to all land uses or to all economically usable activities (European Commission 2015). One could exempt surface not covered by a dwelling and tax only location beneath buildings, but this leads to small dwellings and large surrounding plots, ultimately incites sprawling tendencies. An exemption on the surface covered by building, taxing only unconstructed land also encourages households to fill their location with structures (Dye and England 2009a; European Commission 2015; Zabulenas et al. 2010).

Urban economic activities generally entail residential, commercial, industrial, public, special uses (e.g. non-profit, social, religious, events and sports), and undeveloped urban land. Residential use is the most space-consuming use per capita in cities and suburbs with great infrastructure needs ${ }^{7}$ (European Environment Agency 2013; European Environment Agency 2010; Couch, Leontidou, and Petschel-Held 2007). Taxing residential use would contribute reducing its excessive urban land consumption (Blum 2014; Bringezu 2014; L. E. Brown 2014; European Environment Agency 2010; Zabulenas et al. 2010), increase residential density and reduce transport emissions (Banzhaf and Lavery 2010; Creutzig et al. 2015).

Taxing commercial and industrial use is more controversial; two views coexist. On the one hand businesses are not end payers and LVT would hand additional wedges onto consumers (Richard M. Bird and Slack 2003; R.M. Bird and Slack 2013). But excluding them also subsidizes consumers, as the total costs of production - including business location - are not fully internalized. In practice, governments fear taxing businesses especially if the nearby jurisdictions do it too (Wassmer 2009). But net effects depend on mobility of the business, typically lower in practice than what businesses claim (Wassmer 2009). Besides, commercial activities represent a great share of the tax base in large urban zones

\footnotetext{
${ }^{7}$ In Europe, urban residential land consumption accounts for 20 percent of total land use change in the last decade (European Environment Agency 2013; European Environment Agency 2010; Couch, Leontidou, and Petschel-Held 2007).
} 
(Gutachterausschuss für Grundstückswerte in Berlin 2014; Higgsmith 2013). From a social planer perspective, LVT on commercial use is of particular interest if the net social and environmental benefit of residential space exceeds that of commercial use (Glaeser 2013). In this regard, innovative alternatives suggest the idea of a "sustainable compensation" or "footprint charge" that fully includes production costs (Zwingler 2002; European Environment Agency 2010). With regards to special uses, preferential treatment provides direct community benefits, but also exempts local governments from fiscal responsibilities. It is thus preferable to implement direct subsidies available to all, not just to property owners (Cordes 2012). In practice, exemptions apply to those called non-economically usable, which include non-profit and public and institutional uses ${ }^{8}$ (European Commission 2015). One alternative could be that local governments assess the tax base erosion and perform a cost-benefit analysis (W. Bowman, Cordes, and Metcalf 2009; Cordes 2012). Finally, vacant land encourages development and deters land speculation (Brueckner and Kim 2003), but new development is not always desirable, leading to negative outcomes on society and ecosystems - e.g. withdrawal of land from agriculture may provoke unemployment and urban sprawl- (J. E. Anderson 1986; Douglas 1980; Roakes, Barrows, and Jacobs 1994). An adequate classification of natural and artificial land cover with specific regulation of developable land solves this issue ${ }^{9}$. Even in rapidly growing areas, although a burden on undeveloped land does not ensure contiguous development, it certainly shapes it towards more sustainable urban forms (Brandt 2014; Fainstein 2012; Seto et al. 2014). Based on these observations and for the sake of simplicity to further discuss the effects of a shift towards LVT, we assume relative inelasticity of land supply through the existence of restrictive land use planning.

\subsection{Valuation method}

Valuation methods aim at capturing the spatiotemporal property value change linked to location advantages and disadvantages, and incorporate it into the tax base to provide taxpayers with a sense of fairness (L. C. Walters and Rosengard 2012). Plotspecific appraisals are therefore the most equitable alternative but also administratively unfeasible (Alterman 2011). We focus on the adequacy of different bases of assessment, the technical approaches, and the importance of the frequency of assessments.

\subsubsection{Basis of assessment}

The basis of assessment is the indicator used to obtain a monetary value for the tax base (Johannesson Lindén and Gayer 2012). Market Value (MV) is "the estimated amount for which the property should exchange on the date of valuation between a willing buyer and a willing seller in an arm's length transaction after proper

\footnotetext{
${ }^{8}$ Exemptions in Europe include public infrastructure regardless of its owner (water, electricity, and sewage) (European Commission 2014).

${ }^{9}$ We exclude non-urban artificial land cover like agriculture and other natural land covers.
} 
marketing wherein the parties had each acted knowledgeably, prudently and without being under compulsion" (EU 2013, sec. 56; TEGoVA 2015) ${ }^{10}$. It reflects the expectation of bidders for the most productive permitted use of the location, often referred to as 'Highest and Best Permitted Use' (HBPU). Assessed or cadastral value (CV) is a database with values based on the adjustment of historic MV using diverse factors - age, use, inflation factor, etc.-. Rent refers to inter-temporal value increase. On a general basis, it accounts for a life-time period - location gains (LG)-, but it can also be expressed as Annual Rental Value (AR). This is called recurrent income for non-residential owners and absent owners - the annual income that an owner can expect from renting out the chargeable subject- and imputed income for owner-occupied properties. Flat base appraisals (FB) group properties onto value bands. Lastly, if there is no market, tax agencies base their assessment on stock values and resort to surface areas, the so-called area based assessment (ABA).

FB cancel the need for reassessments, but assume zero relative value variations over time, which makes it regressive and an incentive for space consumption (Mirrlees et al. 2011). ABA is mostly applied in former communist regimes and countries where there is no real estate market (Almy 2013; Bell and Bowman 2009; Riël C.D. Franzsen and William 2008). Governments use it to increase PT yields in relatively short periods, its simplicity is appealing and administrable, and brings clarity and transparency for the first stage of a PT regime (Bell and Bowman 2009). But in the long run $\mathrm{ABA}$ undervalues locations and raises equity concerns (Rao 2008). To include scarce and new market information as the housing market develop one could first weigh the area by indicators of quality and location (Mikesell and Zorn 2008). AR and LG need continuous adjustment to inflation (Richard Miller Bird and Slack 2007). AR also requires substantial administrative undertaking to calculate the tax base, especially in the case of owner-occupied housing where no rents are available from the market, and provides highly volatile values compared to LG, where expectation of future value development are included (Richard M. Bird and Slack 2003). Also, the link between tax obligations and benefits is more explicitly spelt out under LG compared to AR (Kitchen, 2013). MV and CV - if up to date - are the most preferable assessment bases. They forecast value changes both for market agents and local planners (Raslanas et al., 2010). One could say that they discourage people from moving leading to inefficient household allocation and homeownership among infrequent movers at the expense of frequent (O'Sullivan, Sexton, and Sheffrin 1995; Wasi and White 2005). But empirics show that these dynamics benefit low-income homeowners because they move less frequently (O'Sullivan, Sexton, and Sheffrin 1995; Sjoquist and Pandey 2001; Wasi and White

\footnotetext{
${ }^{10}$ Market price is not the same as market value. In a competitive market, the buyer's willingness to pay (market value) might be higher than the market price due to personal preferences; the difference is the "consumer surplus".
}

References 
2005). This said, MV performs best regarding the ability-to-pay principle and land use efficiency (Kitchen 2013; Raslanas 2013).

\subsubsection{How to appraise}

Appraisal agencies typically report location and improvement values separately, but their accuracy varies according to the technique used (Bell, Bowman, and German 2009; Bell and Bowman 2008; Bell and Bowman 2006; E. S. Mills 1998; Netzer 1998). In places with limited assessment capacities, self-assessments and pre-set charges dominate, but resulting inaccurate estimates erode the value capture justification (Alterman 2011; Richard Miller Bird and Slack 2007; Brzeski 2005). The straightest way forward is to assess undeveloped parcels and use the sales comparison approach, where market transactions are adjusted using different characteristics - size, corner influence location, topography, etc.-. But vacant plots are scarce in urban cores and appraisers use mainly four traditional techniques. First, the abstraction approach subtracts the depreciated costs of improvements to the property value. It is an attractive alternative when new development abounds, but as structures become older distortions on residual LV increase. Second, the land share allocates a percentage of the total parcel value to land derived from the market evidence. This comes from the abstraction method, historical sales data of a time where there were enough undeveloped plots, or by comparing data from a nearby jurisdiction. While the first source requires proper calibration of construction costs and depreciation percentages georeferenced, the second and third ones lack in accounting for timing and spatial related changes (Bell, Bowman, and German 2009). Third, the contribution value method calculates the sum of values of each property element and its characteristics - typically differing from total property value (Eckert 1990). Finally, sales data for teardowns discount the demolition costs to the property value (Dye and McMillen 2007b). All these methods use statistical models to calculate the urban property universe (Bell, Bowman, and German 2009; Eckert 1990). However, they show significant weaknesses (Bell, Bowman, and German 2009; E. S. Mills 1998), with the contribution approach providing most accurate results (Bell, Bowman, and German 2009; Bell and Bowman 2006). Either way, it is always better to combine these methods with vacant and improved sales data (Gloudemans, Handel, and Warwa 2002).

Today, appraisers use econometric regressions to develop modern mass appraisals. They estimate both vacant and improved LV with reasonable accuracy, even if few vacant plots data are available (Barker 2007; Case 2007; Davis and Heathcote 2007; Gloudemans 2000). Based on this methodology, Computer Assisted Mass Appraisals (CAMA) estimate hedonic price indexes from a representative sample of sales and apply it to the entire universe of unsold properties. Indexes relate sale prices to physical and location characteristics, where weights are estimated from marginal changes in the physical and location figures and then used to assess unsold properties. Finally, the most accurate methodology is the integration of CAMA into Geographic Information Systems (GIS) technology to 
develop spatially explicit datasets (Aleksiene and Bagdonavicious 2009; Bell, Bowman, and German 2009; Ward et al. 2002). Even with low level of satellite imagery, combining GIS with little on-ground data and international expert support is highly recommended in countries with no sale records or markets in transition (Aleksiene and Bagdonavicious 2009; Eckert 2008). Industrial and commercial inactive markets also benefit from CAMA-GIS because it replicates appraisal procedures more efficiently than traditional per-unit-breakdowns. Benchmarks or proxy sales are adjusted by property characteristics - e.g. size, zoning, retail, apartment, warehouse, motel, heavy manufacturing - and then interpolate between known points to finally obtain the value of unsold properties, including dummy variables to account for additional land use specifics - e.g. primary, unused or rightof-way-(Bell, Bowman, and German 2009).

To sum up, good appraisal practices require a combination of modelling specifications to enhance coefficients from regression models, data enhancement techniques - e.g. working with real estate companies-, GIS technologies, and regularly evaluated standards regardless of whether they are public or private contracted appraisal firms (Bell, Bowman, and German 2009). Also, legislation should specify how the technical approach can avoid variation among municipalities, although the assessment practice must take place at the lower spatial level (Bell, Bowman, and German 2009; Bell and Bowman 2006; Mattsson 2003).

\subsubsection{Frequency}

An updated base is crucial to keep the liability, accountability, transparency and rationale of the tax, but here is where most countries perform worse (Almy 2013; European Commission 2014; Mirrlees and Institute for Fiscal Studies 2011; Smith 2013; UN-HABITAT 2011a; UN-HABITAT 2011b). Governments believe that updating CV makes the PT more visible and creates social and political reluctance, which ultimately costs votes. But out-of-date tax bases lead to unfair fixes, unequal taxation and political disruption. It is thus better to have an annually updated inflation-adjusted $\mathrm{ABA}$ than a $\mathrm{CV}$ above three to five years of age, -depending on the market conditions- (Almy 2013; Cocconcelli and Medda 2013).

\subsection{Elements of differential taxation}

\subsubsection{Liability base}

Liability base, also known as assessment ratio value, is the part of the assessment base to which charge rates are applied (Dye and England 2009b). A split rate tax burdens a higher assessment ratio and/or tax rate to LV as compared to structures. The extreme case - a pure LVT - is when buildings are assessed with zero ratios (Brandt 2014). Assessment ratios adjustments may be delayed a period of time under equity considerations (Ayuntamiento de Madrid 2014; European Commission 2014; European Commission 2015). 


\subsubsection{Tax rate}

There is no consensus on how high or low a tax rate should be; it is intrinsically dependent on the tax purposes - e.g. abatement of previous PT, raise additional revenue - What does seem clear is that rates have to be sufficiently high to a) result in higher tax bill on the affected location, and b) raise enough revenue to cover the administrative costs of the tax (Alterman 2011; Cho et al. 2008; Mirrlees and Institute for Fiscal Studies 2011; Raslanas, Zavadskas, and Kaklauskas 2010; L. C. Walters and Rosengard 2012). Next, for LVT to be a planning instrument, under the condition of inelastic supply of land, as mentioned above, the rate should be high enough to raise enough revenues and change behaviours - the "super neutral" nature of LVT - (Alterman 2011; Calavita et al. 2010; Calavita and Mallach 2009; Terence Dwyer 2014). Looking at the revenue raising from LVT in Europe and other countries, tax rates below 2.5 percentages contribute in a lesser way to local revenues than what the LVT rationale suggests (major contributor of local revenues) (Cord 1985; European Commission 2014; European Commission 2015; F. E. Foldvary 2006). Finally, rates should be flexible to absorb shifts in the tax burdens, e.g. through housing Consumer Price Index (CPI) adjustments (Bourassa 2009).

Generally, municipalities define the tax rates freely or within a given rate, which creates heterogeneity between different locations. Additionally, it is often the case that different tax rates apply to different land uses (e.g. commercial, industrial, residential, etc.) (Richard Miller Bird and Slack 2007; Smolka and Biderman 2011; Waicho Tsui 2008). But discretionary tax rates create additional burdens, leading to unfair circumstances, lobbying, and suboptimal land use allocation, which ultimately hinders appropriate land use mix from an urban sustainability perspective (Alterman 2011; Augustine and Bell 2009) (although discretionary tax rates is less distortive than zoning (Augustine and Bell 2009)).

Together, the liability base and the tax rate should produce a tax liability (what remains when applying the tax rate to the tax base) high enough to foster the land regulation potential of LVT, and to raise enough revenues to cover administrative cost of the tax (Brandt 2014; Dye and England 2009a).

\subsubsection{Exemptions and reliefs}

Exemptions and reliefs are used for two things. First, they neutralize the regressive aspects of PT, especially with regards to low-incomers and elderly owners (Augustine and Bell 2009). Second, they subsidize owner-occupied residential housing, a practice massively applied throughout the $20^{\text {th }}$ century for economic development reasons (Kortelainen and Saarimaa 2015; S. E. Sexton, Wu, and Zilberman 2012).

For the first objective, governments typically use assessment limits to stabilize tax liabilities when property values raise rapidly (T. A. Sexton 2009; Hamilton 2007). But these create unequal redistribution of burdens which undermines the 
fairness of the LVT (Minnesota Department of Revenue 2006; Dye and McMillen 2007a; Dye 2007; Dornfest 2005). Those, whose property values are increasing more rapidly, profit because effective tax rates decline more rapidly the faster the property appreciates at rates above the limit. Next, if assessment limits apply interchangeably to all uses, the burden will shift toward residential owners: their aggregate assessed value increases more rapidly due to turnover because they typically change ownership more frequently (Minnesota Department of Revenue 2006; Dye and McMillen 2007a; Dye 2007; Dornfest 2005). Finally, they erode the tax base and impact government revenues heavily (N. B. Anderson 2006; Minnesota Department of Revenue 2006; Moak 2004; O'Sullivan, Sexton, and Sheffrin 1995; T. A. Sexton 2009; Sjoquist and Pandey 2001). General discretionary exemptions apply according to property or owner characteristics - e.g. low income, disabled; war veterans, etc.-. They have direct social benefits, but these can be more efficiently provided through alternatives that do not discourage owners to seek for higher income or optimum use location (T. A. Sexton 2009).

To subsidise homeownership tax payments can be credited - tax deferrals - or exempted if the income is below a certain threshold. These practices however discourage owners seek for higher or more stable income. Tax deferrals also reduce the expectation value of inheritors, who often find alternative ways to avoid their tax bills. Similarly, mortgage interest deductibility enables taxpayers deduct their tax liability according to their level of indebtedness. This practice creates critical distortions by incentivising private households indebtedness and sprawl (Archer 2010; Couch, Leontidou, and Petschel-Held 2007; Diaz-Serrano and Raya 2014; Hanson, Brannon, and Hawley 2013; Johannesson Lindén and Gayer 2012; S. E. Sexton, $\mathrm{Wu}$, and Zilberman 2012). It produces very low tax payments, while it does little to increase homeownership (Augustine and Bell 2009; Kortelainen and Saarimaa 2015). An increasing agreement exists on the idea that deductibility practices should be replaced by subsidies targeted at low-income first-home buying households instead of a general measure that in practice enables tax avoidance of high income residential owners (Augustine and Bell 2009; Bartlett 2013; Bell, Bowman, and German 2009; J. H. Bowman 2009; Stiglitz 2014).

Literature discussing the externalities of new development or already developed areas with a specific project or public intervention plan refers to a tax relief based on the consumption of new or old urban land to achieve lesser eat up land development (Panella, Zatti, and Carraro 2011). Value capture literature also identifies reliefs based on budgetary and/ or development responsibilities, the so-called conditional reliefs (Ingram and Hong 2012a; Peterson 2009). Finally, there is zoning specific reliefs based on noise, air pollution etc.; a kind of inverse Pigouvian tax (Batt 2011a; Brandt 2014; Kreiser et al. 2011; Panella, Zatti, and Carraro 2011).

All this said, reliefs or exemptions undermine the beneficial aspect of LVT, and limit local spending capacity (Augustine and Bell 2009; Richard M. Bird and Slack 2003). They function in the same way as regulation or an additional tax, but with 
more complex distortions (Barnett and Yandle 2004). Hence, lower and uniform rates are less likely to create distortions than higher and non-uniform rates (Augustine and Bell 2009; Buchanan 1987). Socially based exemptions may be considered in very specific cases by no means are permanent; they need to be constantly revised (Alterman 2011). But even then, direct expenditures are more efficient than tax reliefs (Augustine et al. 2009; Edel and Sclar 1974).

\subsection{Tax liability and collection}

\subsubsection{Liability}

Liability refers to the final payment obligation, often expressed as the effective rate the ratio of the liability change to the market value change-. Effective rates vary due to different factors. Governments may intentionally set the tax liability significantly below market values for political reasons (Waicho Tsui 2008), but it is often the case that they are not aware of the factors behind (Barnett and Yandle 2004; Virtanen 2000). Bahl and Linn (1992) developed a methodology to decompose the tax revenues and identify factors affecting the level of LVT collection. First, the relative growth of property stocks may not follow the overall growth (macroeconomic factors). Policy choices influence the non-exemption ratio, the valuation or assessment ratio, and the tax rate. Lastly, the collection rate falls, to a major extent, under the tax administration authority (Gravelle and Wallace 2009). There is no harmonized suggestion on how high effective rates should be - besides that of uncover administrative costs-, but underrating location values weakens the redistributive effects and hinders significant net yields (Alterman 2011).

\subsubsection{Collection}

The value capture literature uses two criteria for evaluating the instrument that can be applied to a LVT: the percentage of LV captured $\left(\mathrm{R}_{\mathrm{r}}\right)$, and the percentage of public infrastructures investment financed by the LVT $\left(\mathrm{R}_{\mathrm{i}}\right)$ (Hong 2003; Hong 1996;

L. C. Walters 2012). Deciding $R_{i}$ and $R_{r}$ has normative assumptions. Nonetheless the following criteria are strongly recommended: a) $R_{i}$ should take into account investment, operation, and maintenance; b) $R_{\mathrm{r}}$ should be constant over time for equity reasons (Hong 2003; Hong 1996; L. C. Walters 2012).

\subsection{Revenue Recycling}

How to invest the revenues is a highly normative decision where two views compete. The "new view" says that revenue should be redistributed where most needed, regardless the revenue raising location. The "benefit view" suggests that LVT is a benefit tax, thus its benefits should be directly reinserted in the place where they were raised (Alterman 2011; Oates 1969; Oates and Schwab 2009b; Tiebout 1956). 


\subsection{Governance level}

The main argument towards a decentralized LVT relies on the fundamental link between tax and expenditure decisions, assuming competing autonomous municipalities. If finance comes from elsewhere, this link is broken and the choice of programs are not based on true costs (McKinnon and Nechyba 1972; Oates 2001; Oates 1999; Oates 1993; Weingast 1995). To motivate municipalities they should keep full LVT revenues; otherwise collection is not robust enough (Alterman 2011; R.M. Bird and Slack 2013). In metropolitan areas, the local discretion on rates may cause tax competition and socio-economic segregation (Cutler and Glaeser 1997; Glaeser 2013). There is no clear cut solution to this problem but the subsidiarity principle or to a central planning approach may help, where total metropolitan revenues should be inter-municipality redistributed (Alterman 2011).

\subsection{Fiscal Environment}

The interaction of LVT with other forms of property charges varies the outcomes of the instrument. Typically, countries tax LV through non-recurrent instruments. Zoning, land-use charges, development taxes, or transaction taxes are some examples. We do not address these interactions because they are beyond the scope of this paper. Nevertheless, consensus exists on the idea that additional instruments may hinder the potential benefits of LVT (Batt 2011a; Dye and England 2009a; Panella, Zatti, and Carraro 2011; Powers 2009; Raslanas 2013; Zabulenas et al. 2010).

\subsection{Implementation}

LVT often faces political opposition; unpopularity of wealth taxation grows when this is based on unrealized capital gains rather than current cash flow (Bourassa 2009). This makes it a highly contested debate that intersects with political ideologies (Alterman 2011), and may even be perceived as a violation of the state' constitutional principles of uniformity, equality and proportionality (Coe 2009). The philosophical and legal perspective on property rights and land ownership is a key element in the discussion of the viability of LVT. For example, the concept of property used by the European Court on Human Rights could be understood as that appropriation of some part of land value is permitted if it benefits public interest, but appropriation is not permitted to seize the LV produced by someone else but the owner (Carss-Frisk 2001; Council of Europe 1950). This view contrasts with "the unearned value" the UN-HABITAT refers to in the Vancouver Action Plan (UNHABITAT 1976). These dichotomies appear not only at the institutional level, but also between parties from the same country (Alterman 2011). The concept of property changes over time and scale, and so does the legitimacy of taxing away LV. However, although fundamental, the normative discussions go far beyond the scope of this paper. 
Assuming a legal framework that allows the taxation of LV and considering the above, the rationale behind a LVT is of extreme importance, where two main views coexist: the redistribution and justice argument -"capturing the unearned value"-, and the pragmatic view, which seeks to enforce developers pay their share and control development patterns (Alterman 2011; Balchin, Bull, and Kieve 1995; Booth and Albrechts 2012; UN-HABITAT 1976; L. C. Walters 2012). The first one faces administrative and regulatory-based feasibility challenges; the second one faces transparency issues because policies are jointly design by developers and government (Alterman 2011; Fainstein 2012; Meltsner 1971; Smolka and Biderman 2011). Clear rationales (what should be taxed, and why) and national legal frameworks alleviate these challenges. But designs should be flexible enough to accommodate to changing needs for public perceptions on what merit public financing (Alterman 2011; Bourassa 2009; Coe 2009). Predefined assessment standards must apply nationally (Bell, Bowman, and German 2009) and it has to be legally separated. Its revenue and revenue recycling should be reported separately from other taxes to increase awareness and acceptability (Alterman 2011; Bourassa 2009; Coe 2009; Oates 2001; Powers 2009). The other way around, unless taxpayers are ensured adequate level of public services, it will face opposition (Bourassa 2009; Rao 2008).

Next, every tax reform creates winners and losers, and so does LVT. Governments should acknowledge this and ensure that the tax bill is affordable by majority of tax payer (Powers 2009). Taxpayers should have the right to require a revision of the valuation (Aleksiene and Bagdonavicious 2009). To avoid drastic changes, the implementation of an LVT should be best done in combination with a tax shift. This could be gradually introduced through a split tax rate, where there is a simultaneous decrease on improvement rate with increases in rates on location values (Wallace Oates and Robert Schwab 2009). Next, never increase the LVT at the same time as assessments take place (Bourassa 2009). It is also important to minimise administrative costs in the long term - e.g. coordination on data collection and valuation - (Bourassa 2009; Powers 2009; Tiits 2009). Local governments should be aware of macroeconomic forces that may interfere and lead to an apparent failure (Bourassa 2009). Finally, the introduction of a LVT has to go hand in hand with appropriate land use planning that regulates and delimitates developable zones; otherwise overconsumption of land may take place (Bourassa 2009; Riel C. D. Franzsen 2009).

\section{Assessing current practices in Europe}

This section deals with the second question on whether current European practices of LVT are designed according to the criteria from the previous section. We select those European countries that have a kind of LVT. Two inclusion criteria apply: a) the tax base excludes structural private improvements (and thus focuses on some aspect of LV), and b) the tax ownership includes private owners. The evaluation material is based on databases and reports from the European Commission on 
property taxes (European Commission 2014; European Environment Agency 2010; European Commission 2015). We look at the "Grundskyld" in Denmark, the "maamaks" in Estonia, the "compensation for the use of building ground" in Slovenia; the "tax on land" in Slovakia, the "tax on land" in Romania, the tax on "aree edificabili" in Italy (IT), the "telekado" in Hungary, and the "land tax" in Lithuania. Data is from 2014, the latest fiscal year available for all countries. We compare the design characteristics available in the database with the findings of the previous section for each country. Each criterion (a total of 20) is weighted according to whether it fits or not with literature suggestions (no: 0 , yes: 1) (see Table 3 below). Although it is challenging to evaluate normative criteria, we attempt to do it in the following way: To give an intuition on criterion revenue rising (6), although there are no LV databases available, we express the revenues from LVT as share of Gross Domestic Product (GDP), national and recurrent property tax revenues (see Figure 2). For the revenue recycling criterion (7), as there is also no data available on how revenues are allocated, we evaluate it negatively for all countries based on the transparency and accountability criteria (see 3.10 Implementation), same as we do when no data is available for any other criterion ("n.a." entries in Table 3). Grey shadowed entries in Table 3 indicate that the design criteria are appropriate according to the revised literature.

Table 3. Evaluation of current European practices (DK: Denmark; SI: Slovenia; EE: Estonia; SK: Slovakia; RO: Romania; IT: Italy; HU: Hungary; LT: Lithuania; AU: Austria)

\begin{tabular}{|c|c|c|c|c|c|c|c|c|c|}
\hline & DK & SI* & EE & SK & RO & IT & $\mathbf{H U}$ & LT & AT \\
\hline 1. Tax base & $\mathrm{S}[1]$ & $\mathrm{S}$ & $\mathrm{H}$ & LV & $\mathrm{S}$ & $\mathrm{S}$ & $\mathrm{S}$ & $\mathrm{S}$ & $\mathrm{S}$ \\
\hline 2. Owner & $\begin{array}{c}\text { AUO } \\
\text { [2] }\end{array}$ & $\begin{array}{l}\text { AUO } \\
+ \text { US }\end{array}$ & $\begin{array}{l}\text { AUO } \\
\text { - P [3] }\end{array}$ & $\begin{array}{l}\text { AUO } \\
+ \text { US }\end{array}$ & $\begin{array}{l}\text { AUO } \\
+ \text { US }\end{array}$ & AUO & AUO & $\mathrm{PO}[2]$ & AUO \\
\hline 3. Land use & ALU & $\mathrm{V}+\mathrm{L} 1$ & $\begin{array}{c}\text { ALU } \\
{[4]}\end{array}$ & AEU & $\begin{array}{l}\text { AEU } \\
-\mathrm{L} 1\end{array}$ & $\mathrm{~V}$ & $\mathrm{~L} 2+\mathrm{V}$ & $\mathrm{ALU}$ & $\mathrm{V}$ \\
\hline $\begin{array}{l}4.1 \text { Basis of } \\
\text { assessment }\end{array}$ & MV & $\mathrm{ABA}$ & $\mathrm{CV}$ & $\mathrm{CV}$ & $\mathrm{ABA}$ & $\begin{array}{l}\mathrm{AR} \\
{[5]}\end{array}$ & $\begin{array}{c}\mathrm{ABA} / \\
\mathrm{MV}[6]\end{array}$ & $\mathrm{CV}$ & $\mathrm{CV}$ \\
\hline $\begin{array}{l}4.2 \text { Frequency } \\
\text { (stipulated/ last } \\
\text { year) }\end{array}$ & 2 & 1 & $\begin{array}{c}6 \\
(2001)\end{array}$ & (2004) & na. & $\begin{array}{c}(198 \\
8)\end{array}$ & n.a. & $\begin{array}{c}5 \\
(2013)\end{array}$ & n.a. \\
\hline 4.3 How to appraise & $\mathrm{SC}$ & $\mathrm{CON}[7]$ & $\begin{array}{l}\mathrm{CON} / \\
\mathrm{SC}[8]\end{array}$ & $\mathrm{CON}$ & $\mathrm{CON}[9]$ & $\begin{array}{c}\mathrm{CON} \\
{[7]}\end{array}$ & SA & CAMA & na. \\
\hline $\begin{array}{l}\text { 5.1 Assessment } \\
\text { ratio (\%) }\end{array}$ & 81 & n.a. & 66 & 72 & na. & 100 & $50[10]$ & 100 & n.a. \\
\hline 5.2 Tax rate (\%) & $\begin{array}{l}2.60 \\
{[11]}\end{array}$ & [12] & $\begin{array}{l}1.30 \\
{[13]}\end{array}$ & [14] & [15] & $\begin{array}{c}0.4 \\
{[16]}\end{array}$ & $1.5[17]$ & $1.5[18]$ & 1 \\
\hline $\begin{array}{l}5.3 \text { Exemptions and } \\
\text { reliefs: ownership }\end{array}$ & $\begin{array}{l}\text { NP; IP } \\
\text { [19] }\end{array}$ & $\begin{array}{l}\text { P [20]; } \\
\text { LI [21] }\end{array}$ & $\begin{array}{l}\text { D [19]; } \\
\text { PO(RE } \\
\text { S) [22] }\end{array}$ & $\begin{array}{l}\mathrm{R} ; \mathrm{NP} ; \\
\mathrm{EDU} \\
\mathrm{HEA}\end{array}$ & $\begin{array}{c}\mathrm{R} ; \mathrm{NP} ; \\
\mathrm{EDU} ; \\
\mathrm{HEA} ; \\
\mathrm{WV} ; \mathrm{D}\end{array}$ & $\begin{array}{c}\mathrm{R} ; \\
\mathrm{NP} ; \\
\text { EDU } \\
; \\
\text { HEA }\end{array}$ & $\begin{array}{c}\mathrm{PO} \\
\text { (RES) } \\
{[27]}\end{array}$ & LI, D & - \\
\hline $\begin{array}{l}5.4 \text { Exemptions and } \\
\text { reliefs: land use }\end{array}$ & I & I; L1[23] & $\mathrm{N}[24]$ & [25] & $\begin{array}{c}\mathrm{I} ; \mathrm{IND} ; \\
\mathrm{SPK} ; \mathrm{N} \\
{[26]}\end{array}$ & n.a. & n.a. & $\mathrm{I} ; \mathrm{NR}$ & $\begin{array}{r}\mathrm{ZN} \\
{[28]}\end{array}$ \\
\hline
\end{tabular}


Table 3 cont.

\begin{tabular}{|c|c|c|c|c|c|c|c|c|c|}
\hline & DK & $\mathrm{SI}^{*}$ & $\mathbf{E E}$ & SK & RO & IT & $\mathbf{H U}$ & LT & AT \\
\hline 5.5 Temporality & PER & PER & TEM & PER & PER & PER & PER & PER & TEMP \\
\hline 6. Revenue raising & \multicolumn{9}{|c|}{ See Fig. 2} \\
\hline $\begin{array}{l}\text { 7. Revenue } \\
\text { recycling }\end{array}$ & \multicolumn{9}{|c|}{ na } \\
\hline 8.1 Tax Base & $\bar{C}$ & $\mathrm{~L}$ & $\mathrm{C} / \mathrm{L}$ & $\mathrm{L}$ & $\mathrm{C}$ & $\mathrm{C}$ & $\mathrm{L}$ & $\mathrm{C}$ & $\mathrm{C}$ \\
\hline 8.2 Tax Rate & $C(L)$ & L & $\mathrm{C}(\mathrm{L})$ & $\begin{array}{l}\text { LUZ( } \\
\text { L) }\end{array}$ & $\mathrm{C}$ & $\mathrm{C} / \mathrm{L}$ & $\mathrm{L}$ & $\mathrm{L}$ & $\mathrm{C}$ \\
\hline 8.3 Reliefs & $\mathrm{C} / \mathrm{L}$ & $\mathrm{L}$ & $\mathrm{C} / \mathrm{L}$ & $\mathrm{L}$ & $\mathrm{C} / \mathrm{L}$ & $\mathrm{C} / \mathrm{L}$ & $\mathrm{L}$ & $\mathrm{C} / \mathrm{L}$ & $\mathrm{C}$ \\
\hline 8.4 Collection & $\mathrm{L}$ & $\mathrm{C}$ & $\mathrm{C}$ & $\mathrm{L}$ & $\mathrm{L}$ & $\mathrm{C}$ & $\mathrm{L}$ & $\mathrm{C}$ & $\mathrm{C}$ \\
\hline 8.5 Revenues & L & L & L & $\mathrm{L}$ & $\mathrm{L}$ & $\mathrm{C} / \mathrm{L}$ & $\mathrm{L}$ & L & $\mathrm{C}$ \\
\hline $\begin{array}{l}\text { 9. Fiscal } \\
\text { Environment }\end{array}$ & Yes & Yes & Yes & Yes & Yes & Yes & Yes & Yes & Yes \\
\hline $\begin{array}{l}\text { Buildings and } \\
\text { apartments }\end{array}$ & $\mathrm{x}$ & $\mathrm{x}$ & & $\mathrm{x}$ & $\mathrm{x}$ & LUX & $\mathrm{x}$ & $\begin{array}{l}\text { BUSS, } \\
\text { LUX }\end{array}$ & $\mathrm{x}$ \\
\hline Capital gains & 0.24 & 0.1 & 0.21 & 0.19 & 0 & 0 & 0.16 & 0.15 & 0.25 \\
\hline Land Use Change & $\mathrm{x}$ & $\mathrm{x}$ & - & - & - & $\mathrm{x}$ & - & - & - \\
\hline Gift and inheritance & $\mathrm{X}$ & $\mathrm{X}$ & - & $\mathrm{x}$ & & $\mathrm{x}$ & $\mathrm{x}$ & $\mathrm{x}$ & - \\
\hline Transactions & $\mathrm{x}$ & $\mathrm{x}$ & - & $\mathrm{x}$ & $\mathrm{x}$ & $\mathrm{x}$ & $\mathrm{x}$ & - & $\mathrm{x}$ \\
\hline $\begin{array}{l}\text { Mortgage } \\
\text { registration }\end{array}$ & - & - & - & - & - & $\mathrm{x}$ & - & - & - \\
\hline $\begin{array}{l}\text { Imputed rent of } \\
\text { residential owners }\end{array}$ & - & na. & - & - & na. & na. & n.a. & - & n.a. \\
\hline $\begin{array}{l}\text { Luxury value } \\
\text { criterion }\end{array}$ & $\mathrm{x}$ & n.a. & - & - & na. & $\mathrm{x}$ & - & $\mathrm{X}$ & no \\
\hline 10. Implement. & & & & & $\mathrm{na}$ & & & & \\
\hline $\begin{array}{l}\text { Score } \\
(\max .20)\end{array}$ & 11 & 3 & 5 & 7 & 3 & 4 & 5 & 8 & 5 \\
\hline
\end{tabular}

* Tax abolished in 2014.

[1] Until 2013, private non-structural improvements were excluded; [2] A separated LVT applies to Public ownership; [3] Excluded: municipal land and land in public use. Included: state land not in public use [4] Included: exploitation minerals; [5] From cadastre; [6] Municipalities choose either $50 \%$ of $\mathrm{MV}$; or L2 + V; [7] Factors: plot size; municipality; location zone; land use coefficient; infrastructure availability; [8] Valuation authorities allowed to consider all available evidence: e.g. sales comparison, estimation of value for HBPU; [9] Factors: plot size; municipality; location; land use coefficient; [10] For MV basis; [11] 1.6$3.4 \%$, average 2.6\%; [12] Each parcel assessed in absolute amount; [13] 0.1-2.5\%, average $1.3 \%$; [14] Up to 5 times the lowest rate set by another municipality; [15] Lump sum per square meter; [16] 0.2 -0.4\%; [17] 0- 3\%;[18] 0.1- 4\%, average 1.5\%; [19] Optional; [20] Exemption; [21] Reduction; [22] Formerly repressed persons if not receiving rent for leasing out land; [23] During 5 years after construction; [24] RES: Area up to 0.15 ha exempted; NR: $50 \%$ reduced rate; [25] Exempt if NEU due to natural state or zoning; [26] Exemption: land for subsoil exploitation, water bodies; [27] $25 \mathrm{~m}^{2}$ per resident; $50 \%$ lower: land where building is not permitted; [28] Private ownership recovers tax payment if dwelling built within 5 years. 


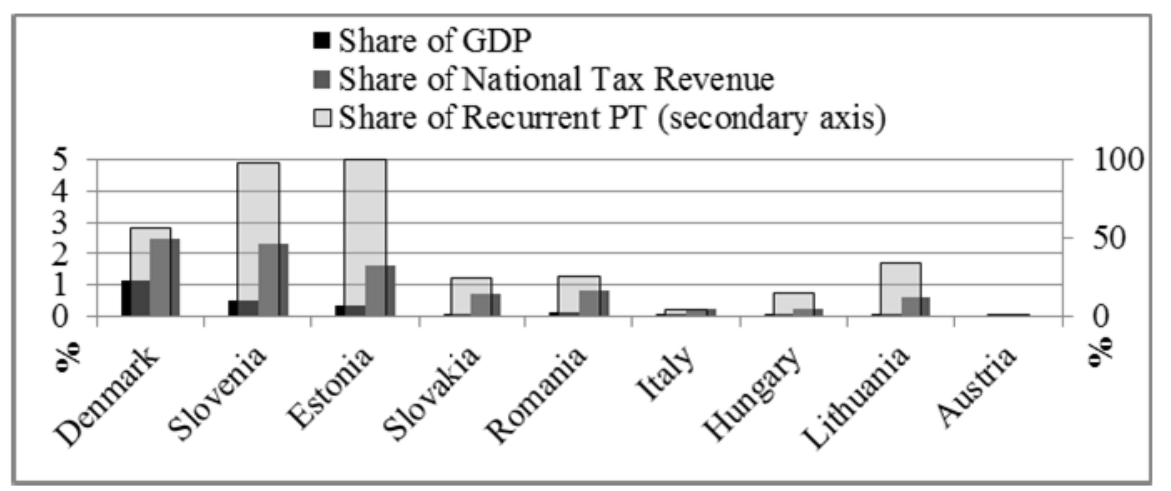

Figure 2. LVT revenues expressed in GDP, national and recurrent property taxes revenues (secondary axis).

This evaluation demonstrates that Denmark is the best practice in Europe, followed by Slovenia and Slovakia. Denmark also had a pure LVT until 2013, which has not been recorded in the evaluation, as we use data from 2014. Lithuania is currently developing a LVT with improved design; considerable effort is made in updating cadastral values (last update 2013). For Slovenia, although it also has a well-designed tax, it is worthwhile mentioning that the Constitutional Court recently abolished the tax. In Estonia, for every property there is an area up to 0.15 hectares exempted since 2013, which erodes the tax base enormously. Looking at the revenue raised expressed as share of GDP and share of national tax revenue, Denmark is followed by Slovenia and Estonia (Fig.2 most and second most dark grey in the graph). Interestingly, the latter two base their share of recurrent property taxes solely on the LVT (Fig.2 light grey, secondary axis).

\section{Discussion and Conclusion}

A vast amount of research from public economics to sustainability science indicates that a shift from traditional PT towards LVT improves specific sustainability metrics: it increases fiscal efficiencies and raises revenue to pay back low carbon infrastructure investment, it fosters denser development and decreases urban land consumption, and it redistributes wealth accumulated in real estate cycles given by LV and not by private investment". To understand how design characteristics enhance urban sustainability, we homogenise nomenclature and revise the normative statements behind LVT. We also present a framework that organizes alternative design decision, together with a discussion on the sustainability effects from each of them. Fields of urban economics and public finance address issues of equity, and efficiency (socio-economic outcomes). Value capture and sustainable transport literatures provide mixed insights on the sufficiency and equity arguments. Urban planning and sustainability sciences address the issue of land consumption and environmental effects. All together, they stress the following crucial elements in the design of a LVT for its outcomes: the importance of how the tax base is designed 
the valuation method that is used -especially the frequency of assessments-, the disturbances of exemptions and tax reliefs together with other property taxes in place. In addition, strong land use regulations is very much encouraged for dealing with environmental concerns, especially with regard to reducing land use consumption.

Overall, we find that location value tax is of relevance in the urban sustainability debate and, with adaptive policy instruments, should be considered in planning integrated strategies for sustainable cities. We also suggest that a quantitative assessment would be desirable, enabling the quantification of not only financial but also ecological and societal effects of the proposed tax reform. A shift towards LVT would enhance the overall sustainability outcome of the real estate taxation system.

In Europe, although there are good practices with regards to some criteria (e.g. assessment ratios, governance level, and tax subject definition), most countries fail our evaluation. In other words, there is considerable room for improvement in most countries, especially by improving the tax base, the frequency of assessment practices, and abolishing additional property taxes that distort the outcome of LVT. But countries like Slovenia illustrate the enormous legal difficulties a LVT has to overcome, not always successfully. As it prioritises urban planning objectives that interfere with incentives for economic development - e.g. profitability for developers-, supporters must be able to package a rationale that transcends party ideologies. In societies where private control of land is firmly embedded, resistance to limiting speculative profit is greater and will be opposed politically. Thus, many states prefer indirect instruments designed to collect contributions from developers to meet the infrastructure needs- e.g. betterment ad public ownership, agreements, to obligations and community infrastructure levies- (Alterman 2011). At the European level, the few research projects are quite disperse and either look at its potential for spatial planning and environmental policy (Altes 2009; European Environment Agency 2010) or on abstract economic rationales (Mattauch, Siegmeier, and Edenhofer 2013; Mattauch et al. 2013). Interestingly, there are a number of places where LVT is gaining attention (Alterman 2011; Brandt 2014; Terry Dwyer 2003; Dye and England 2010; European Commission 2012; Land Value Tax Working Party 2005; Panella, Zatti, and Carraro 2011; Tom and Kris 1999). In Europe, the UK (Mirrlees and Institute for Fiscal Studies 2011; Seely 2013a; Wightman 2013), Scotland (Wightman 2010), Ireland (Gurdgiev 2010; Gurdgiev 2009; Inter-Departamental Group 2012) and the Netherlands (Altes 2009) openly debate the issue. In particular, Greece would greatly benefit from implementing a land registry and a location value tax, obtaining stable tax revenue with less regressive effects compared to high levels of value added taxes. The European Statistical Office (EUROSTAT) and the Organisation for Economic Cooperation and Development (OECD) have a joint project to develop methodological guidelines for LV estimation that will be applied in future tax systems reviews at the EU level (European Commission 2012; Garnier et al. 2013). This initiative may 
indeed further stimulate the discussion on LVT. Neither urban sustainability nor location taxes are easy to impose. There are logistical and institutional hurdles, where politics is the hardest one. But the underlying rationale of a levy on locations for financing public expenses is compelling.

\section{Acknowledgements}

We gratefully acknowledge the funding received towards one of the author's $\mathrm{PhD}$ from the Heinrich Boell Foundation $\mathrm{PhD}$ fellowship.

\section{References}

Albouy, David. 2009. "What Are Cities Worth. Land Rents, Local Productivity, and the Capitalization of Amenity Values." Working Paper 14981. Cambridge, MA: National Bureau of Economic Research.

. 2012. "Metropolitan Land Values and Housing Productivity." Working Paper 18110. Cambridge, MA: National Bureau of Economic Research.

Aleksiene, Albina, and Arvydas Bagdonavicious, eds. 2009. "Value-Based Property Taxes in Lithuania." In Erosion of the Property Tax Base: Trends, Causes, and Consequences, 411-46. Cambridge, Mass.: Lincoln Institute of Land Policy.

Almy, Richard R. 2013. "Property Tax Regimes in Europe." The Global Urban Economic Dialogue Series. Nairobi: UN-HABITAT. http://unhabitat.org/?wpdmact=process\&did=MTkwLmhvdGxpbms=.

Alterman, Rachelle. 2011. "Chapter 33: Land-Use Regulations and Property Values: The 'windfalls Capture' idea Revisited." In The Oxford Handbook of Urban Economics and Planning, 755-86. New York: Oxford University Press.

Altes, Willem K. Korthals. 2009. "Taxing Land for Urban Containment: Reflections on a Dutch Debate." Land Use Policy 26 (2): 233-41. doi:10.1016/j.landusepol.2008.01.006.

Anderson, John E. 1986. "Property Taxes and the Timing of Urban Land Development." Regional Science and Urban Economics 16 (4): 483-92. doi:10.1016/0166-0462(86)90019-0.

- 2009. "A Review of the Evidence." In Land Value Taxation: Theory, Evidence, and Practice, Richard F. Dye and Richard W. England. Cambridge, MA: Lincoln Institute of Land Policy.

Anderson, Nathan B. 2006. "Property Tax Limitations: An Interpretative Review." National Tax Journal 59 (3): 685-94.

Archer, Ken. 2010. "Would Mortgage Tax Reform Slow Sprawl and Gentrification?" Greater Greater Washington, November 12. http://greatergreaterwashington.org/post/8090/would-mortgage-tax-reform-slowsprawl-and-gentrification/.

Arnott, Richard. 2011. "Chapter 3: What Planners Need to Know about The 'new Urban Economics." In The Oxford Handbook of Urban Economics and Planning. New York: Oxford University Press. 
Arnott, Richard J., and Joseph E. Stiglitz. 1979. "Aggregate Land Rents, Expenditure on Public Goods, and Optimal City Size." The Quarterly Journal of Economics 93 (4): 471. doi:10.2307/1884466.

Augustine, Nancy Y., and Michael E. Bell, eds. 2009. "Property Tax Exemptions, Revenues, and Equity." In Erosion of the Property Tax Base: Trends, Causes, and Consequences, 51-72. Cambridge, Mass.: Lincoln Institute of Land Policy.

Augustine, Nancy Y., Michael E. Bell, David Brunori, and Joan M. Youngman, eds. 2009. Erosion of the Property Tax Base: Trends, Causes, and Consequences. Cambridge, Mass.: Lincoln Institute of Land Policy.

Ayuntamiento de Madrid. 2014. "Impuesto Sobre Bienes Inmuebles (IBI). Tipos de Gravamen."

http://www.madrid.es/portales/munimadrid/es/Inicio/Ayuntamiento/Hacienda/Po rtal-del-Contribuyente/Impuesto-sobre-Bienes-Inmuebles-IBI-Tipos-degravamen?vgnextfmt $=$ default\&vgnextoid $=077 \mathrm{c} 9636 \mathrm{cdf} 68310 \mathrm{VgnVCM} 2000000$ c205a0aRCRD\&vgnextchannel=7c4c9ad016e07010VgnVCM100000dc0ca8c0R CRD\&idioma $=$ es\&idiomaPrevio $=$ es\&rmColeccion $=43963$ ee $5358 \mathrm{c} 6110 \mathrm{VgnVC}$ M1000000b205a0aRCRD.

Bahl, Roy W., and Johannes F. Linn. 1992. Urban Public Finance in Developing Countries. 10597. Published for the World Bank [by] Oxford University Press.

Balchin, Paul N., Gregory H. Bull, and Jeffrey L. Kieve. 1995. Urban Land Economics and Public Policy. 5th Edition edition. Houndmills, Basingstoke, Hampshire: Palgrave Macmillan.

Banzhaf, H. Spencer, and Nathan Lavery. 2010. "Can the Land Tax Help Curb Urban Sprawl. Evidence from Growth Patterns in Pennsylvania." Journal of Urban Economics 67 (2): 169-79. doi:10.1016/j.jue.2009.08.005.

Barker, D. 2007. "Urban Land Rents in the United States." In Land Policies and Their Outcomes, ed. G.K. Ingram and Y.-H. Hong. Cambridge, Mass: Lincoln Institute of Land Policy.

Barnett, A.H., and B. Yandle. 2004. "Regulation by Taxation." In Handbook of Public Finance, Backhaus, J.G. and Wagner, R.E. (Eds.), 217-36. Boston: Kluwer Academic Publ.

Barrett, Claer. 2015. "Tiny UK Explorer Makes Big Claim of Oilfields near Gatwick." Financial Times, April 9. http://www.ft.com/cms/s/0/5b316402-de8411e4-b9ec-00144feab7de.html\#axzz3WtTrwIpf.

Bartlett, Bruce. 2013. "Taxing Homeowners as If They Were Landlords." The New York Times. Economix: Exploring the Science of Everyday Life. September 3. http://economix.blogs.nytimes.com/2013/09/03/taxing-homeowners-as-if-theywere-landlords/.

Batt, H. William. 2011a. "Taxing Land Rents for Urban Livability and Sustainability." In Environmental Taxation and Climate Change: Achieving Environmental Sustainability Through Fiscal Policy. Cheltenham, UK. Northampton, MA: Edward Elgar Publishing Ltd.

_ 2011b. "Taxing Land Rents for Urban Liveability and Sustainability." In Environmental Taxation and Climate Change: Achieving Environmental 
Sustainability Through Fiscal Policy. Cheltenham, UK. Northampton, MA: Edward Elgar Publishing Ltd.

Bell, Michael E., and John H. Bowman. 2006. "Methods of Valuing Land for Real propertytaxation:An Examination of Practices in States That Require Separate Valuation of Land and Improvements." Working Paper. Cambridge, MA: Lincoln Institute of Land Policy.

- 2008. "Consistency of Land Vlues: Comparison of Three General Approaches to Valuing Land Where There Are Few Vacant Land Sales." Working Paper. Cambridge, MA: Lincoln Institute of Land Policy.

—. , eds. 2009. "Extending Property Taxation into Previously Untaxed Areas: South African Townships and Tribal Areas." In Erosion of the Property Tax Base: Trends, Causes, and Consequences, 334-71. Cambridge, Mass.: Lincoln Institute of Land Policy.

Bell, Michael E., John H. Bowman, and Jerome C. German. 2009. "The Assessment Requirements for a Separate Tax on Land." In Land Value Taxation: Theory, Evidence, and Practice, Richard F. Dye and Richard W. England, 129-94. Cambridge, MA: Lincoln Institute of Land Policy.

Bird, Richard M., and Enid Slack. 2003. "Land and Property Taxation: A Review." In World Bank: Innovations in Local Revenue Mobilization. Washington, D.C: World Bank. http://www1.worldbank.org/publicsector/decentralization/June2003Seminar/Lan dPropertyTaxation.pdf.

Bird, Richard Miller, and Enid Slack. 2007. "Taxing Land and Property in Emerging Economies: Raising Revenue... and More?" In Land Policies and Their Outcomes, edited by Gregory K Ingram and YU-Hung Hong, 204-33. Cambridge, MA: Lincoln Institute of Land Policy.

Bird, R.M., and E. Slack. 2013. "Metropolitan Public Finance: An Overview." In Financing Metropolitan Governments in Developing Countries, Wetzel, D.L., Linn, J.F. and Bahl, R.W. (Eds.), 135-158. Cambridge, Mass: Lincoln Institute of Land Policy.

Blum, Winfried. 2014. "Potential and Limits of Sustainable Intensification of Agriculture." In European Commission Land as a Resource. Brussels. http://ec.europa.eu/environment/land_use/conference_en.htm.

Booth, Philip A., and Louis G. H. Albrechts. 2012. "The Unearned Increment: Property and the Capture of Betterment Value in Britain and France." In Value Capture and Land Policies, Edited by Gregory K. Ingram and Yu-Jung Hong, 74-96. Cambridge, Massachusetts: Lincoln Institute of Land Policy,.

Bourassa, Steven C. 2009. "The Political Economy of Land Value Taxation." In Land Value Taxation: Theory, Evidence, and Practice, Richard F. Dye and Richard W. England, 129-94. Cambridge, MA: Lincoln Institute of Land Policy.

Bowman, John H., ed. 2009. "Residential Property Tax Reliefs Measures: A Review and Assessment." In Erosion of the Property Tax Base: Trends, Causes, and Consequences, 17-50. Cambridge, Mass.: Lincoln Institute of Land Policy.

Bowman, Woods, Joseph Cordes, and Lori Metcalf, eds. 2009. "Preferential Tax Treatment of Property Used for Social Purposes: Fiscal Impacts and Public 
Policy Implications." In Erosion of the Property Tax Base: Trends, Causes, and Consequences, 269-306. Cambridge, Mass.: Lincoln Institute of Land Policy.

Brandt, Nicola. 2014. "Greening the Property Tax." OECD Working Papers on

Fiscal Federalism 17. OECD Publishing. Paris, France: OECD. http://dx.doi.org/10.1787/5jz5pzw9mwzn-en.

Bringezu, Stefan. 2014. "A Finite World and Increasing Land Demands: A Global Perspective." In European Commission Land as a Resource. Brussels.

Brown, H. James, and Martim O. Smolka. 1997. "Capturing Public Value from Public Investments." In Land Use and Taxation: Applying the Insights of Henry George, ed H. J. Brown. Cambridge, MA: Lincoln Inst of Land Policy.

Brown, L.E. 2014. "The Importance of Land in the 21st Century." In . Brussels.

Brueckner, Jan K. 1986. "A Modern Analysis of the Effects of Site Value Taxation." National Tax Journal 39 (1): 49-58.

- 2000. "Urban Sprawl: Diagnosis and Remedies." International Regional Science Review 23 (2): 160-171.

Brueckner, Jan K., and Hyun-A. Kim. 2003. "Urban Sprawl and the Property Tax." International Tax and Public Finance 10 (1): 5-23.

Brzeski, Jan. 2005. "Bringing Area Based Formula Closer to Market: India and Poland." In . Prague (Czchek Republic).

Buchanan, James M. 1987. Public Finance in Democratic Process: Fiscal Institutions and the Individual Choice. UNC Press Books.

Calavita, Nico, Joaquim Clusa, Sara Mur, and Robert Weiner. 2010. "Spain's Constitutional Mandates: The Right to Housing, Land Value Recapture, and Inclusionary Housing." In Inclusionary Housing in International Perspective: Affordable Housing, Social Inclusion, and Land Value Recapture, ed. iIco Calavita and Alan Mallach, 239-74. Cambridge, Mass.: Lincoln Institute of Land Policy.

Calavita, Nico, and Alan Mallach. 2009. "Inclusionary Housing, Incentives, and Land Value Recapture." Land Lines 21: 15-21.

Carss-Frisk, Monica. 2001. "The Right to Property: A Guide to the Implementation of Article 1 of Protocol No. 1 to the European Convention on Human Rights." Human rights handbooks 4. Strasbourg Cedex: Council of Europe.

Case, K.E. 2007. "The Importance of Land Value in Today's Economy." In Land Policies and Their Outcomes, ed. Gregory K. Ingram and Yu-Hung Hong. Cambridge, Mass.: Lincoln Institute of Land Policy.

Cho, Seong-Hoon, Dayton M. Lambert, Roland K. Roberts, and Seung Gyu Kim. 2008. "Moderating Urban Sprawl through Land Value Taxation." In American Agricultural Economics Association Anmual Meeting. Orlando, FL. http://ageconsearch.umn.edu/bitstream/6150/2/468873.pdf.

Clark, Gregory, and Eric Jamelske. 2005. "The Efficiency Gains from Site Value Taxes: The Tithe Commutation Act of 1836." Asian Economic Growth and Development 42 (2): 282-309. doi:10.1016/j.eeh.2004.07.003.

Cocconcelli, Luca, and Francesca Romana Medda. 2013. "Boom and Bust in the Estonian Real Estate Market and the Role of Land Tax as a Buffer." Land Use Policy 30 (1): 392-400. doi:10.1016/j.landusepol.2012.04.007. 
Coe, Richard D. 2009. "The Legal Framework in the United States." In Land Value Taxation: Theory, Evidence, and Practice, 129-94. Cambridge, Mass: Lincoln Institute of Land Policy.

Cord, Steven. 1985. "How Much Revenue Would a Full Land Value Tax Yield?" American Journal of Economics and Sociology 44 (3): 279-93. doi:10.1111/j.1536-7150.1985.tb02344.x.

Cordes, Joseph. 2012. "Assessing the Nonprofit Property Tax Exemption: Should Nonprofit Entities Be Taxed for Using Local Public Goods?" In Value Capture and Land Policies, ed. Gregory K. Ingram and Yu-Hung Hong, 353-401. Cambridge, MA: The Lincoln Institute of Land Policy.

Couch, Chris, Lila Leontidou, and Gerhard Petschel-Held, eds. 2007. Urban Sprawl in Europe. Landscapes, Land-Use Change and Policy. Oxford, UK: Blackwell Publishing Ltd.

Council of Europe. 1950. Article 1 of Protocol No. 1 to the European Convention for the Protection of Human Rights and Fundamental Freedoms, as Amended by Protocols Nos. 11 and 14. ETS 5.

Creutzig, Felix, Giovanni Baiocchi, Robert Bierkandt, Peter-Paul Pichler, and Karen C. Seto. 2015. "Global Typology of Urban Energy Use and Potentials for an Urbanization Mitigation Wedge." Proceedings of the National Academy of Sciences, January, 201315545. doi:10.1073/pnas.1315545112.

Cutler, David M., and Edward L. Glaeser. 1997. "Are Ghettos Good or Bad?" The Quarterly Journal of Economics 112 (3): 827-72. doi:10.1162/003355397555361.

Davis, Morris A., and Jonathan Heathcote. 2007. "The Price and Quantity of Residential Land in the United States." Journal of Monetary Economics 54 (8): 2595-2620. doi:10.1016/j.jmoneco.2007.06.023.

Dempsey, N., C. Brown, and G. Bramley. 2012. "The Key to Sustainable Urban Development in UK Cities? The Influence of Density on Social Sustainability." Progress in Planning 77 (3): 89-141. doi:10.1016/j.progress.2012.01.001.

Dempsey, Nicola, Glen Bramley, Sinéad Power, and Caroline Brown. 2011. "The Social Dimension of Sustainable Development: Defining Urban Social Sustainability." Sustainable Development 19 (5): 289-300. doi:10.1002/sd.417.

Dexia, and CEMR. 2012. "Subnational Public Finance in the European Union." Dexia Crédit Local, Council of European Municipalities and Regions. http://www.eetaa.gr/enimeroseis/17-01-13/Note_CCRE_Dexia_EN.pdf.

Diaz-Serrano, Luis, and Josep M. Raya. 2014. "Mortgages, Immigrants and Discrimination: An Analysis of the Interest Rates in Spain." Regional Science and Urban Economics 45 (March): 22-32. doi:10.1016/j.regsciurbeco.2013.12.004.

Dillman, K.N., and L.M. Fisher. 2009. "Land Registration, Economic Development, and Poverty Reduction." In Property Rights and Land Policies, ed. Gregory K. Ingram and Yu-hung Hong, 25-51. Cambridge, MA: Lincoln Institute of Land Policy.

Doerner, William M., and Keith R. Ihlanfeldt. 2011. "House Prices and City Revenues." Regional Science and Urban Economics, Special Issue: The Effect 
of the Housing Crisis on State and Local Governments Published in collaboration with the Lincoln Institute of Land Policy, 41 (4): 332-42. doi:10.1016/j.regsciurbeco.2011.02.004.

Dornfest, Alan S. 2005. "Effects of Taxable Value Increase Limits: Fables and Fallacies." Journal of Property Tax Assessment \& Administration 2 (4): 5.

Douglas, Richard W. 1980. "Site Value Taxation and the Timing of Land Development." American Journal of Economics and Sociology 39 (3): 289-94. doi:10.1111/j.1536-7150.1980.tb01280.x.

Dwyer, Terence. 2014. "Taxation: The Lost History." American Journal of Economics and Sociology 73 (4): 664-988. doi:10.1111/ajes.12082_3.

Dwyer, Terry. 2003. "The Taxable Capacity of Australian Land and Resources." Australian Tax Forum 18: 21-68.

Dye, Richard F. 2007. "The Algebra of Tax Burden Shifts from Assessment Limitations." Working Paper. Cambridge, MA: Lincoln Institute of Land Policy.

Dye, Richard F., and Richard W. England, eds. 2009a. Land Value Taxation: Theory, Evidence, and Practice. Cambridge, MA: Lincoln Institute of Land Policy.

- 2009b. "The Principles and Promises of Land Value Taxation." In Land Value Taxation: Theory, Evidence, and Practice, Richard F. Dye and Richard W. England. Cambridge, MA: Lincoln Institute of Land Policy.

_ 2010. "Assessing the Theory and Practice of Land Value Taxation." Policy Focus Report PF025. Cambridge, MA: Lincoln Institute of Land Policy.

Dye, Richard F., and Daniel P. McMillen. 2007a. "Surprise! An Unintended Consequence of Assessment Limitations." Land Lines 19 (3): 8-13.

- 2007b. "Teardowns and Land Values in the Chicago Metropolitan Area." Journal of Urban Economics 61 (1): 45-63. doi:10.1016/j.jue.2006.06.003.

Eckert, Joseph K., ed. 1990. Property Appraisal and Assessment Administration. Chicago, Ill: Intl Assn of Assessing Off.

— . ed. 2008. "Computer-Assisted Mass Appraisal (CAMA) Options for Transitional and Developing Countries." In Making the Property Tax Work: Experiences in Developing and Transitional Countries, Edited by Roy Bahl, Jorge Martinez-Vazquez and Joan Youngman, 207-38. Cambridge, Mass: Lincoln Institute of Land Policy.

Edel, Matthew, and Elliott Sclar. 1974. "Taxes, Spending, and Property Values: Supply Adjustment in a Tiebout-Oates Model." Journal of Political Economy 82 (5): 941-54.

England, Richard W. 2003. "State and Local Impacts of a Revenue-Neutral Shift from a Uniform Property to a Land Value Tax: Results of a Simulation Study." Land Economics 79 (1): 38. doi:10.2307/3147103.

_. , ed. 2007. "Land Value Taxation as a Method of Financing Municipal Expenditures in US Cities." In Land Policies and Their Outcomes, ed. Gregory K. Ingram and Yu-hung Hong, 185-200. Cambridge, Mass.: Lincoln Institute of Land Policy. 
England, Richard W, and Mohan Ravichandran. 2010. "Property Taxation and Density of Land Development: A Simple Model with Numerical Simulations." Eastern Economic Journal 36 (2): 229-38. doi:10.1057/eej.2009.7.

EU. 2013. Regulation (EU) No 575/2013 of the European Parliament and of the Council of 26 June 2013 on Prudential Requirements for Credit Institutions and Investment Firms and Amending Regulation (EU) No 648/2012. 575/2013. http://www.boe.es/buscar/act.php?id=BOE-A-2004-4163.

European Commission. 2012. "Possible Reforms for Real Estate Taxation - Criteria for Successful Policies." Occasional Papers 119.

—. 2014. "Tax Reforms Database." Database. Taxes in Europe - Tax Reforms", Database

(TEDB/TAXREF).

http://ec.europa.eu/taxation_customs/taxation/gen_info/info_docs/tax_inventory/ index_en.htm.

— 2015. "Tax Revenue Statistics." Eurostat. http://ec.europa.eu/taxation_customs/resources/documents/taxation/gen_info/eco nomic_analysis/tax_structures/2014/report.pdf.

European Environment Agency. 2010. "Land in Europe: Prices, Taxes and Use Patterns." EEA Technical report 4/2010. Copenhagen.

—. 2013. "Land Take (CSI 014/LSI 001)." June. http://www.eea.europa.eu/data-and-maps/indicators/land-take-2/assessment-2.

Fainstein, Susan S. 2012. "Land Value Capture and Justice." In Value Capture and Land Policies, ed. Gregory K. Ingram and Yu-Hung Hong, 21-40. Cambridge, MA: The Lincoln Institute of Land Policy.

Fernandez Milan, Blanca. 2015. "How Participatory Planning Processes for TransitOriented Development Contribute to Social Sustainability." Journal of Environmental Studies and Sciences, January, 1-5. doi:10.1007/s13412-0140217-5.

Foldvary, Fred. 2010. The Science of Economics. Santa Clara, California: Cognella.

Foldvary, Fred E. 2006. "The Ultimate Tax Reform: Public Revenue from Land Rent." Policy Study ID 1103586. Rochester, NY: Civil Society Institute.

—. 2008. "The Marginalists Who Confronted Land." American Journal of Economics and Sociology 67 (1): 89-117. doi:10.1111/j.15367150.2007.00561.x.

Franzsen, Riel C. D. 2009. "International Experience." In Land Value Taxation: Theory, Evidence, and Practice, 27-50. Cambridge, Mass: Lincoln Institute of Land Policy.

Franzsen, Riël C.D., and J. McCluskey William. 2008. "The Feasibility of Site Value Taxation." In Making the Property Tax Work: Experiences in Developing and Transitional Countries, Edited by Roy Bahl, Jorge Martinez-Vazquez and Joan Youngman, 268-306. Cambridge, Mass: Lincoln Institute of Land Policy.

Gaffney, Mason. 2009. "The Hidden Taxable Capacity of Land: Enough and to Spare." Internet Journal of Social Economics 36 (4): 328-411.

Garnier, Gaëlle, Aleksandra Gburzynska, Endre György, Milena Mathe, Doris Prammer, Savino Ruà, and Agnieszka Skonieczna. 2013. "Recent Reforms of Tax Systems in the EU: Good and Bad News." Taxation Paper 39. Directorate 
General Taxation and Customs Union, European Commission. http://econpapers.repec.org/paper/taxtaxpap/0039.htm.

George, Henry. 1879. Progress and Poverty. Gloucestershire, UK: Dodo Press.

Glaeser, Edward L. 2013. "Chapter 4 - Urban Public Finance." In Handbook of Public Economics, edited by Alan J. Auerbach, Raj Chetty, Martin Feldstein and Emmanuel Saez, Volume 5:195-256. Elsevier.

Gloudemans, R.J. 2000. "Implementing a Land Value Tax in Urban Residential Communities." Working Paper. Cambridge, MA: Lincoln Institute of Land Policy.

Gloudemans, R.J., S. Handel, and M. Warwa. 2002. "An Empirical Evaluation of Alternative Land Valuation Models.” Working Paper. Cambridge, MA: Lincoln Institute of Land Policy.

Gravelle, Jennifer, and Sally Wallace, eds. 2009. "Overview of the Trends in Property Tax Base Erosion." In Erosion of the Property Tax Base: Trends, Causes, and Consequences, 17-50. Cambridge, Mass.: Lincoln Institute of Land Policy.

Grosskopf, Shawna. 1981. "The Revenue Potential of Site Value Tax: Extension and Update of General Equilibrium Model With Recent Empirical Estimates of Several Key Parameters." American Journal of Economics and Sociology 40 (2): 207-15. doi:10.1111/j.1536-7150.1981.tb01389.x.

Gurdgiev, Constantin. 2009. "Macroeconomic Case for a Land Value Tax Reform in Ireland." Smart Taxes Network, Policy Paper. http://papers.ssrn.com/sol3/papers.cfm?abstract_id=2029519.

- 2010. "Land Value Tax in Ireland. Revenue Potential in Post-Crisis Equilibrium." Trinity College, Dublin, October.

Gutachterausschuss für Grundstïckswerte in Berlin. 2014. Bodenrichtwertabfrage (BRW-Online). http://fbinter.stadt-berlin.de/boris/?session_id=2005576326.

Hamilton, Billy. 2007. "Proposition 13's Long Shadow." State Tax Notes June 11: 831-34.

Hanson, Andrew, Ike Brannon, and Zackary Hawley. 2013. "The Geographic Distribution of the Mortgage Interest Deduction.” Federal Impact, Mortgages. Fiscal Federalism Initiative. The Pew Charitable Trusts. http://www.pewstates.org/research/reports/the-geographic-distribution-of-themortgage-interest-deduction-85899471375.

Harrison, Fred. 2014. "Dynamics of the Statecraft of Greed: First of Ten Theses." Share the Rents. http://www.sharetherents.org/thesis/statecraft-of-greed/.

Higgsmith, Yonatan. 2013. The Taxing Question of Land. www.taxingqofland.org. Hong, Yu-Hung. 1996. "Can Leasing Public Land Be an Alternative Source of Local Public Finance?" Working Paper WP96YH2. Cambridge, MA: Lincoln Institute of Land Policy.

2003. "Policy Dilemma of Capturing Land Value under the Hong Kong Public Leasehold System." In Leasing Public Land: Policy Debates and International Experiences, ed. S.C. Bourassa and Y.-H. Hong. Cambridge, Mass.: Lincoln Institute of Land Policy. 
Hubacek, Klaus, and Jeroen C.J.M. van den Bergh. 2006. "Changing Concepts of 'land' in Economic Theory: From Single to Multi-Disciplinary Approaches." Ecological Economics 56 (1): 5-27. doi:10.1016/j.ecolecon.2005.03.033.

Huxley, Joe. 2009. "Value Capture Finance. Making Urban Development Pay Its Way." ULI, Urban Land Institute.

Ingram, Gregory K. 2008. "Note on Measuring Changes in Capital/Land Ratios Related to Tax Changes." Working Paper WP08GI2. Lincoln Institute of Land Policy.

Ingram, Gregory K., and Yu-hung Hong. 2012a. "Land Value Capture: Types and Outcomes." In Value Capture and Land Policies, Edited by Gregory K. Ingram and Yu-Jung Hong, 3-18. Cambridge, MA: Lincoln Institute of Land Policy,.

Ingram, Gregory K., and YU-Hung Hong. 2012b. Value Capture and Land Policies. Cambridge, MA: Lincoln Institute of Land Policy.

Institute for Fiscal Studies, and James Mirrlees, eds. 2011. "Chapter 16: The Taxation of Land and Property." In Tax By Design: The Mirrlees Review, 1sted. Oxford, UK: Oxford University Press.

Inter-Departamental Group. 2012. "Design of a Local Property Tax." Ireland. http://www.environ.ie/en/PublicationsDocuments/FileDownLoad,31669, en.Pdf.

Johannesson Lindén, A., and C. Gayer. 2012. "Possible Reforms of Real Estate Taxation: Criteria for Successful Policies." 119. European Economy Occasional Papers. Brussels: Europ. Comm. Directorate General for Economic and Financial Affairs.

Kaza, Nikhil, and Gerrit-Jan Knaap. 2011. "Chapter 2: Principles of Planning for Economists." In The Oxford Handbook of Urban Economics and Planning, 2950. New York: Oxford University Press.

Kitchen, Harry. 2013. "Property Tax: A Situation Analysis and Overview." In $A$ Primer on Property Tax: Administration and Policy, edited by William KJ McCluskey, Gary C. Cornia, and Lawrence C. Walters. Oxford, United Kingdom: Blackwell Publishing Ltd. http://www.pbookshop.com/media/filetype/s/p/1355551386.pdf.

Kortelainen, Mika, and Tuukka Saarimaa. 2015. "Do Urban Neighborhoods Benefit from Homeowners? Evidence from Housing Prices." SSRN Scholarly Paper ID 2539771. Rochester, NY: Social Science Research Network. http://papers.ssrn. com/abstract $=2539771$.

Kreiser, Larry, Julsuchada Sirisom, Hope Ashiabor, and Janet E. Milne. 2011. Environmental Taxation and Climate Change: Achieving Environmental Sustainability Through Fiscal Policy. Cheltenham, UK. Northampton, MA: Edward Elgar Publishing Ltd.

Kunce, Mitch, and Jason F. Shogren. 2008. "Efficient Decentralized Fiscal and Environmental Policy: A Dual Purpose Henry George Tax." Ecological Economics 65 (3): 569-73. doi:10.1016/j.ecolecon.2007.08.004.

Land Value Tax Working Party. 2005. "The Oxfordshire Land Value Tax Study."

Lim, Duck-Ho. 1992. "The Nonneutrality of the Land Value Tax: Impacts on Urban Structure." Journal of Urban Economics 32 (2): 186-94. 
Luca, Cocconcelli. 2011. "Land Value Capture as a Funding Source for Urban Investment: Implementation Issues." ERSA Summer School - European Investment Bank, Luxembourg, July 11.

Lutz, Byron, Raven Molloy, and Hui Shan. 2011. "The Housing Crisis and State and Local Government Tax Revenue: Five Channels." Regional Science and Urban Economics, Special Issue: The Effect of the Housing Crisis on State and Local Governments Published in collaboration with the Lincoln Institute of Land Policy, 41 (4): 306-19. doi:10.1016/j.regsciurbeco.2011.03.009.

Mathur, Shishir, and Adam Smith. 2013. "Land Value Capture to Fund Public Transportation Infrastructure: Examination of Joint Development Projects' Revenue Yield and Stability." Parking 30 (0): 327-335. doi:10.1016/j.tranpol.2013.09.016.

Mattauch, Linus, Jan Siegmeier, and Ottmar Edenhofer. 2013. "Hypergeorgism: When Is Rent Taxation as a Remedy for Insufficient Capital Accumulation Socially Optimal?" CESifo Working Paper.

Mattauch, Linus, Jan Siegmeier, Ottmar Edenhofer, and Felix Creutzig. 2013. "Financing Public Capital through Land Rent Taxation: A Macroeconomic Henry George Theorem." 4280. CESifo Working Paper.

Mattsson, H. 2003. "Site Leasehold in Sweden: A Tool to Capture Land Value." In Leasing Public Land: Policy Debates and International Experiences, ed. S.C. Bourassa and Y.-H. Hong. Cambridge, Mass.: Lincoln Institute of Land Policy.

Maxwell, Dominic, and Anthony Vigor, eds. 2005. Time for Land Value Tax. UK: Institute for Public Policy Research Press.

McCluskey, William J., and Riel C. D. Franzsen. 2005. Land Value Taxation: An Applied Analysis. Aldershot: Ashgate Pub Co.

McKinnon, Ronald I., and Thomas J. Nechyba. 1972. "Competition in Federal Systems: The Role of Political and Financial Constraints." In The New Federalism: Can the States Be Trusted?, J. Ferejohn and B. Weingast, 3-61. Stanford: Hoover Institution Press.

Medda, Francesca. 2012. "Land Value Capture Finance for Transport Accessibility: A Review." Journal of Transport Geography 25 (November): 154-61. doi:10.1016/j.jtrangeo.2012.07.013.

Meltsner, Arnold J. 1971. The Politics of City Revenue the Oakland Project. 1st edition. Berkeley: University of California Press.

Mikesell, John L., and C. Kurt Zorn, eds. 2008. "Data Challenges in Implementing a Market Value Property Tax: Market and Market-Informed Valuation in Russia, Ukraine, and the Baltic States." In Making the Property Tax Work: Experiences in Developing and Transitional Countries, Edited by Roy Bahl, Jorge MartinezVazquez and Joan Youngman, 183-206. Cambridge, Mass: Lincoln Institute of Land Policy.

Mill, John Stuart. 1985. Principles of Political Economy. New issue of 1909 ed. Augustus M Kelley Publishers.

Mills, David E. 2001. "Land Value Taxation." Regional Science and Urban Economics 31 (6): 765-70. doi:10.1016/S0166-0462(01)00068-0. 
Mills, E.S. 1998. "The Economic Consequences of a Land Tax." In Land Value Taxation: Can It and Will It Work Today?, ed. D. Netzer. Cambridge, MA: Lincoln Institute of Land Policy.

Minnesota Department of Revenue. 2006. "Limited Market Value Report: 2005 Assessment Year Taxes Payable." St. Paul: Tax Research Division.

Mirrlees, James, and Institute for Fiscal Studies, eds. 2011. "Chapter 16: The Taxation of Land and Property." In Tax By Design: The Mirrlees Review. Also available as: eBook.

Moak, Casey \& Associates. 2004. "Appraisal Limits: A Wrong Turn on the Road to Property Tax Relief?” Austin, TX: A report to the Texas Association of Property ta Professionals.

Musgrave, Richard A. 1974. "Is a Property Tax on Housing Regressive?" The American Economic Review 64 (2): 222-29.

Nechyba, TJ. 1998. "Replacing Capital Taxes with Land Taxes: Efficiency and Distributional Implications with an Aplication to the United States Economy." In Land Value Taxation: Can It and Will It Work Today? Vol. 31. Cambridge, Massachusetts: Lincoln Institute of Land Policy. http://ideas.repec.org/a/eee/regeco/v31y2001i5p634-641.html.

Netzer, Dick. 1998. "The Relevance and Feasibility of Land Value Taxation in the Rich Countries." In Land Value Taxation: Can It and Will It Work Today?, ed. D. Netzer. Cambridge, MA: Lincoln Institute of Land Policy.

Nuissl, Henning, and Christoph Schroeter-Schlaack. 2009. "On the Economic Approach to the Containment of Land Consumption." Environmental Science \& Policy 12 (3): 270-80. doi:10.1016/j.envsci.2009.01.008.

Oates, Wallace E. 1969. "The Effects of Property Taxes and Local Public Spending on Property Values: An Empirical Study of Tax Capitalization and the Tiebout Hypothesis." Journal of Political Economy 77 (6): 957-71.

—. 1993. "Fiscal Decentralization and Economic Development." National Tax Journal 46 (2): 237-43.

1999. "An Essay on Fiscal Federalism." Journal of Economic Literature 37: $1120-49$.

. 2001. "Property Taxation and Local Government Finance: An Overview and Some Reflections." In Property Taxation and Local Government Finance, Edited by Wallace E. Oates, 21-32. Cambridge, MA: Lincoln Institute of Land Policy.

Oates, Wallace E., and Robert M. Schwab. 1997. "The Impact of Urban Land Taxation: The Pittsburgh Experience." National Tax Journal 50 (1): 1-21.

- 2009a. "The Simple Analytics of Land Value Taxation." In Land Value Taxation: Theory, Evidence, and Practice, Richard F. Dye and Richard W. England. Cambridge, Mass.: Lincoln Institute of Land Policy.

_ 2009b. "The Simple Analytics of Land Value Taxation." In Land Value Taxation: Theory, Evidence, and Practice, 51-72. Cambridge, Mass: Lincoln Institute of Land Policy. 
O'Sullivan, Arthur, Terri A. Sexton, and Steven M. Sheffrin. 1995. "Property Taxes, Mobility, and Home Ownership." Journal of Urban Economics 37 (1): 107-29. doi:10.1006/juec.1995.1007.

Özdilek, Ünsal. 2011. "Land Value: Seven Major Questions in the Analysis of Urban Land Values." American Journal of Economics and Sociology 70 (1): 3049. doi:10.1111/j.1536-7150.2010.00762.x.

Panella, Giorgio, Andrea Zatti, and Fiorenza Carraro. 2011. "Land Management and Local Taxation in Italy." In Environmental Taxation and Climate Change: Achieving Environmental Sustainability Through Fiscal Policy. Cheltenham, UK. Northampton, MA: Edward Elgar Publishing Ltd.

Park, Joon. 2014. "Land Rent Theory Revisited." Science \& Society 78 (1): 88-109.

Peterson, George E. 2009. "Unlocking Land Values to Finance Urban Infrastructure." 7. Trends and Policy Options. Washington, D.C.: The World Bank.

https://www.ppiaf.org/sites/ppiaf.org/files/publication/Trends\%20Policy\%20Opt ions-7-Unlocking\%20Land\%20Values\%20-GPeterson.pdf.

Powers, Sally, ed. 2009. "Collection and Enforcement of the Property Tax." In Erosion of the Property Tax Base: Trends, Causes, and Consequences, 372-85. Cambridge, Mass.: Lincoln Institute of Land Policy.

Rao, U.A. Vasanth. 2008. "Is Area-Based Assessment an Alternative, an Intermediate Step, or an Impediment to Value-Based Taxation in India." In Making the Property Tax Work: Experiences in Developing and Transitional Countries, Edited by Roy Bahl, Jorge Martinez-Vazquez and Joan Youngman, 241-67. Cambridge, Mass: Lincoln Institute of Land Policy.

Raslanas, Saulius. 2013. "A Proposal for Real Estate Tax Reform in Lithuania and Land Value Tax Impacts on Sustainable Development.” Mercator Research Institute of Global Commons and Climate Change, July 29.

Raslanas, Saulius, Edmundas Kazimieras Zavadskas, and Artūras Kaklauskas. 2010. "Land Value Tax in the Context of Sustainable Urban Development and Assessment. Part I - Policy Analysis and Conceptual Model for the Taxation System on Real Property." International Journal of Strategic Property Management 14 (1): 73-86. doi:10.3846/ijspm.2010.06.

Recktenwald, Horst Claus, and Adam Smith. 1999. Der Wohlstand der Nationen: Eine Untersuchung seiner Natur und seiner Ursachen. 12thed. Vol. 30149. Vollständige Ausgabe nach der 5.Aufl. letzter Hand, London 178. München: Deutscher Taschenbuch Verlag.

Roakes, Susan L., Richard Barrows, and Harvey M. Jacobs. 1994. "The Impact of Land Value and Real Property Taxation on the Timing of Central City Redevelopment." Journal of Planning Education and Research 13 (3): 174-84. doi:10.1177/0739456X9401300302.

Rosenzweig, Cynthia, William D. Solecki, Stephen A. Hammer, and Shagun Mehrotra. 2011. Climate Change and Cities: First Assessment Report of the Urban Climate Change Research Network (ARC3). Cambridge, UK: Cambridge University Press. 
Rybeck, Rick. 2004. "Using Value Capture to Finance Infrastructure and Encourage Compact Development." Public Works Management \& Policy 8 (4): 249-60. doi: $10.1177 / 1087724 X 03262828$.

Seely, Antony. 2013a. "Land Value Taxation in the United Kingdom Official Debate - Notes." UK Parliament: House of Commons Library.

_ 2013b. "Land Value Taxation." Standard Note SN6558. England: House of Commons Library.

Seto, Karen C., Shobhaka Dhakal, Anthony Bigio, Hilda Blanco, Gian Carlo Delgado, David Deward, Luxin Huang, et al. 2014. "Human Settlements, Infrastructure and Spatial Planning." In Climate Change 2014: Mitigation of Climate Change. Contribution of Working Group III to the Fifth Assessment Report of the Intergovernmental Panel on Climate Change, Edenhofer, O., R. Pichs-Madruga, Y. Sokona, E. Farahani, S. Kadner, K. Seyboth, A. Adler, I. Baum, S. Brunner, P. Eickemeier, B. Kriemann, J. Savolainen, S. Schlömer, C. von Stechow, T. Zwickel and J.C. Minx (eds.). Cambridge, United Kingdom and New York, NY, USA: Cambridge University Press.

Sexton, Steven E., JunJie Wu, and David Zilberman. 2012. "How High Gas Prices Triggered the Housing Crisis: Theory and Empirical Evidence." Working Paper 34. Berkeley, California: UC Center for Energy and Environmental Economics.

Sexton, Terry A., ed. 2009. "Assessment Limits as a Means of Limiting Homeowner Property Taxes." In Erosion of the Property Tax Base: Trends, Causes, and Consequences, 117-48. Cambridge, Mass.: Lincoln Institute of Land Policy.

Sjoquist, David L., and Lakshmi Pandey. 2001. "An Analysis of Aquisition Value Property Tax Assessment for Homesteaded Property." Public Budgeting and Finance Winter: 1-17.

Skaburskis, Andrejs. 1995. "The Consequence of Taxing Land Value." Journal of Planning Literature 10 (1): 3-21. doi:10.1177/088541229501000101.

Smith, Adam. 2013. Wohlstand der Nationen. Anaconda Verlag.

Smolka, Martim O., and Ciro Biderman. 2011. "Chapter 35: Housing Informality: An Economist's Perspective on Urban Planning." In The Oxford Handbook of Urban Economics and Planning, 814-33. New York: Oxford University Press.

Song, Yan, and Yves Zenou. 2006. "Property Tax and Urban Sprawl: Theory and Implications for US Cities." Journal of Urban Economics 60 (3): 519-34. doi:10.1016/j.jue.2006.05.001.

Stiglitz, Joseph E. 2014. "Reforming Tax to Promote Growth and Equity." Roosevelt Institute. http://www.ictd.ac/en/reforming-tax-promote-growth-andequity.

TEGoVA. 2015. "TEGoVA Guidance on the Interpretation of the Definition of Market Value under the Capital Requirements Regulation (CRR)." The European Group of Valuers' Associations (TEGoVA).

The Economist. 2015. "Space and the City." The Economist, April 4. $\mathrm{http} / /$ www.economist.com/news/leaders/21647614-poor-land-use-worldsgreatest-cities-carries-huge-cost-space-and-city.

Tiebout, Charles M. 1956. "A Pure Theory of Local Expenditures." Journal of Political Economy 64 (5): 416-24. 
Tiits, Tambet, ed. 2009. "Land Taxation Reform in Estonia." In Erosion of the Property Tax Base: Trends, Causes, and Consequences, 395-410. Cambridge, Mass.: Lincoln Institute of Land Policy.

Tom, Gihring, and Nelson Kris. 1999. "Tax Shift Sequential to a Land-Based Property Tax System in Salem, Oregon." Oregon (USA): Marion County (Oregon), Department of Assessments.

UN-HABITAT. 1976. "The Vancouver Action Plan. D. Land." In Habitat: United Nations Conference on Human Settlements. Vancouver, Canada: United Nations. http://www.un-documents.net/vp-d.htm.

_ 2011a. "Innovative Land and Property Taxation." Nairobi, Kenya: UNON, Publishing Services Section.

2011b. Land and Property Tax - A Policy Guideline. Edited by Lawrence C. Walters. Nairobi, Kenya: UNON, Publishing Services Section.

Virtanen, P. 2000. "Chapter 12: Finland." In Land-value: Taxation around the World, Studies in Economic Reform and Social Justice, Andelson, R.V. and Samuels, W.J. (Eds.), 211-20. Malden, MA: Blackwell Publ.

Waicho Tsui, Steve, ed. 2008. "Alternative Value Capture Instruments: The Case of Taiwan." In Making the Property Tax Work: Experiences in Developing and Transitional Countries, Edited by Roy Bahl, Jorge Martinez-Vazquez and Joan Youngman, 127-61. Cambridge, Mass: Lincoln Institute of Land Policy.

Walters, Lawrence C. 2012. "Land Value Capture in Policy and Practice." In . Washington, D.C: Brigham Young University.

Walters, Lawrence C., and Jay K. Rosengard. 2012. "Are Property-Related Taxes Effective Value Capture Instruments?" In Value Capture and Land Policies, Edited by Gregory K. Ingram and Yu-Jung Hong, 187-216. Cambridge, Massachusetts: Lincoln Institute of Land Policy.

Walters, Lawrence W. 2012. "Are Property-Related Taxes Effective Value Capture Instruments?" In Value Capture and Land Policies, ed. Gregory K. Ingram and Yu-Hung Hong, 187-214. Cambridge, MA: The Lincoln Institute of Land Policy.

Ward, Ricahrd, jason Guilford, Brian Jones, Debbie Pratt, and Jerome C. German. 2002. "Piecing Together Location: Three Studies by the Lucas County Research and Development Staff." Assessment Journal 9 (5): 15.

Wasi, Nada, and Michelle J. White. 2005. "Property Tax Limitations and Mobility: The Lock-in Effect of California's Proposition 13.” Working Paper 11108. National Bureau of Economic Research. http://www.nber.org/papers/w11108.

Wassmer, Robert, ed. 2009. "Property Tax Abatement as a Means of Promoting State and Local Economic Activity." In Erosion of the Property Tax Base: Trends, Causes, and Consequences, 221-70. Cambridge, Mass.: Lincoln Institute of Land Policy.

Weingast, Barry R. 1995. "The Economic Role of Political Institutions: MarketPreserving Federalism and Economic Development." Journal of Law, Economics, \& Organization 11 (1): 1-31. 
Wightman, Andy. 2010. "A Land Value for Scotland. Fair, Efficient, Sustainable. A Report Prepared by Andy Wightman for the Green MSPs in the Scottish Parliament." Scotland: Land Matters.

. 2013. "A Land Value Tax for England. Fair, Efficient, Sustainable." England: Land Matters. http://www.andywightman.com/archives/2351.

Youngman, Joan M. 2002. "Enlarging the Property Tax Debate - Regressivity and Fairness." State Tax Notes 26 (1): 45-52.

Zabulenas, Arunas Remigiju, Arturas Kaklauskas, Saulius Raslanas, and Edmundas Kazimieras Zavadskas. 2010. "Land Value Tax in the Context of Sustainable Urban Development and Assessment. Part II - Analysis of Land Valuation Techniques. The Case of Vilnius." International Journal of Strategic Property Management, no. 2: 173-190.

Zanon, Bruno, and Sara Verones. 2013. "Climate Change, Urban Energy and Planning Practices: Italian Experiences of Innovation in Land Management Tools." Land Use Policy 32 (May): 343-55. doi:10.1016/j.landusepol.2012.11.009.

Zhao, Zhirong, Michael Iacono, Adeel Lari, and David Levinson. 2012. "Value Capture for Transportation Finance." Procedia - Social and Behavioral Sciences, Transport Research Arena 2012, 48: 435-48. doi:10.1016/j.sbspro.2012.06.1023. Zwingler, G. 2002. "Entwicklung Eines Planungsinstrumentariums Zur Nachhaltigen Gemeindeentwicklung." Graz: Institut für Volkswirtschaftslehre, Karl-Franzens-Universität Graz. 